\title{
The Origin-Destination Airport Choice for All-Cargo Aircraft Operations in Europe
}

\begin{abstract}
In this paper, we analyze the origin-destination airport choice for freighter operations of combination and all-cargo carriers in Europe. First, we discuss the choice process of airlines qualitatively. Next, using a stated choice experiment, we show that the presence of forwarders at an airport is the primary factor in explaining airlines' choices, especially for airlines serving main airports. For airlines primarily serving regional airports, the possibility for night-time flights is most important. Finally, the presence of passenger operations at an airport is not a significant factor and the level of origin-destination demand is of limited importance.
\end{abstract}

Keywords: air cargo; discrete choice; stated preference; airport choice; multinomial logit model; panel mixed logit model 


\section{Introduction}

During the last 35 years, air transport has known a strong growth. While from 1975 to 2012 passenger transport, measured in passenger kilometers, has been growing at a yearly average of $5.8 \%$, cargo transport, measured in tonne-kilometers, has been growing at a yearly average of $6.2 \%$ (calculations based on ICAO data). Although this strong growth has been tempered by the economic downturn, airports still play an increasingly important role in economies around the world. Many economic impact studies of air transport, mostly on country or airport level (see, e.g., Hakfoort et al. (2001) and Kupfer and Lagneaux (2009)), confirm this increasing importance for the creation of employment and value added. Moreover, on the global level, the impact of aviation is estimated to be 2.2 trillion dollar (Air Transport Action Group, 2012). The strong growth of air transport, on the other hand, also has negative impacts, such as congestion and (noise) pollution.

Because airports can be important for economies in the creation of value, attractive and competitive airports are desirable, especially from a government's point of view. As Starkie (2002) points out, the real market power of an airport depends on the market segment and the availability of other airports in the proximity. While airport competition and airport market power have already been discussed by numerous authors (see Forsyth et al. (2010) and Starkie (2008), for instance), they have mostly been associated with passenger transport. Concerning the competition for air cargo, very little research has been done so far. However, as air cargo transport is a relatively foot-loose business, airport competition for cargo can be quite fierce, especially in Europe, where main airports are often located within a few hours of driving from each other. Therefore, a good understanding of the airport choice of cargo airlines is needed for airports and governments in order to be able to attract cargo airlines and thus economic activity.

In order to understand the background of our research as well as to be able to interpret the results, a closer look at the air cargo sector is required (see Figure 1). In air transport, we distinguish different kinds of airlines. The first type of airlines are pure passenger airlines such as Ryanair, which only organize the transport of people. The second type consists of combination carriers which focus on passenger transport as well, but in addition also deal with the transportation of freight. Integrators (i.e. FedEx, DHL, UPS, TNT), the third type, as well as all-cargo carriers, the fourth type of airlines, focus on the transport of freight and are not involved with the transport of passengers.

Another distinction can be made based on the way in which cargo is transported. Cargo can, for example, be transported in the belly of a passenger aircraft together with the baggage of passengers. Alternatively, cargo can be transported in combi-aircraft which are aircraft in which cargo as well as passengers are transported on the main deck. Last, airlines can use aircraft dedicated to freight transport, i.e. so-called freighters or all-cargo aircraft. 


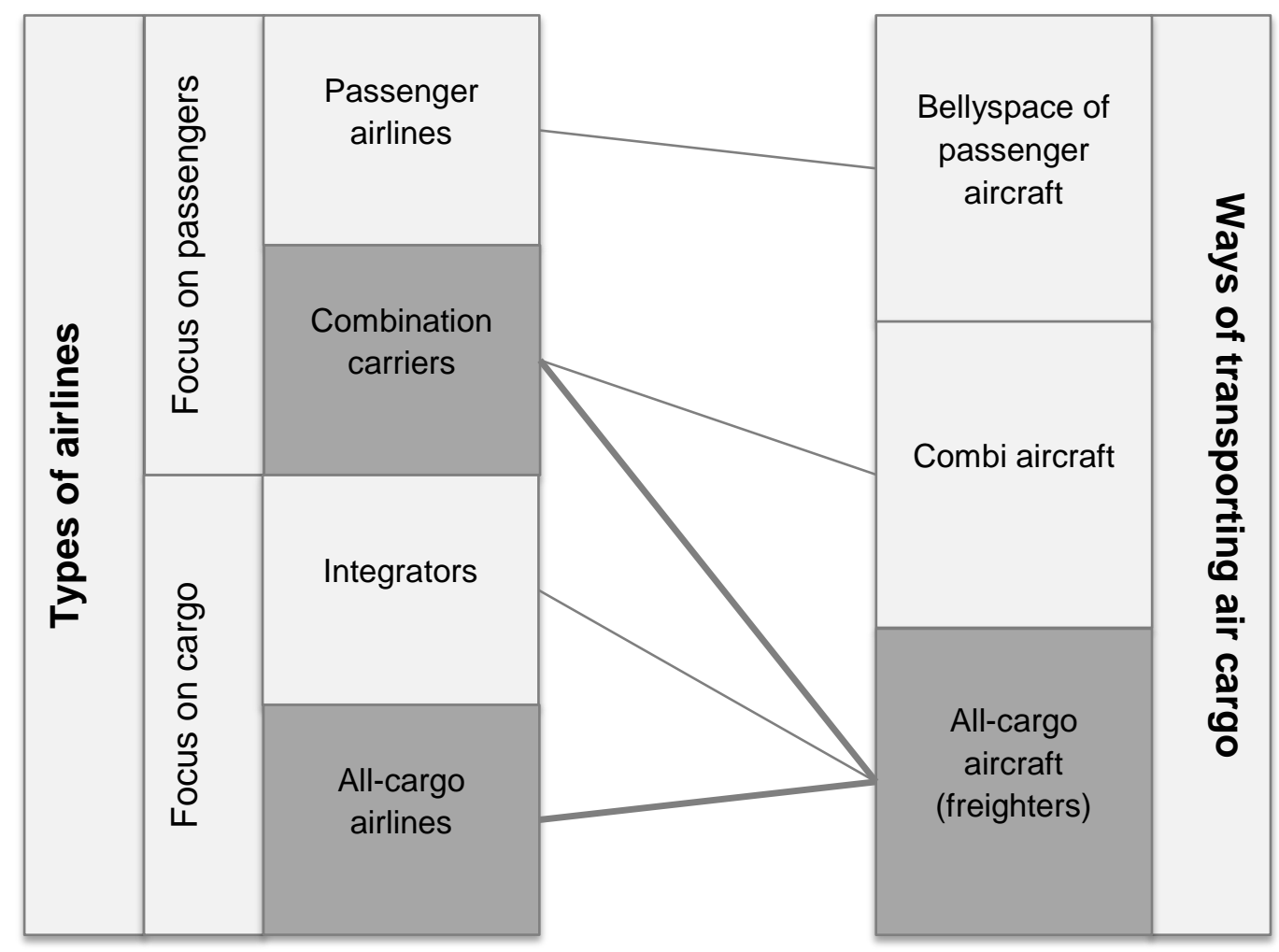

\section{Figure 1 - Air cargo background and research scope}

From the mid '70s up until about 2005, the share of cargo transported in freighters (expressed in tonnekilometers) grew from about $40 \%$ to $60 \%$ of overall air freight traffic. After 2005 , this share dropped again, to about 50\% in 2012 (calculations based on IATA data). Although carriers transport cargo in the belly of a passenger aircraft as well as in freighter aircraft, this article focuses on the airport choice for the latter as the airport choice for belly freight is to a large extent influenced by passenger operations. Furthermore, this study is restricted to the airport choice for freighter operations of combination carriers, as well as the airport choice of all-cargo carriers. Integrators such as DHL and FedEx are not included in our study as their business model is very different from that of the traditional carriers, and, therefore, the factors determining competition between airports are evaluated differently by integrators and combination or allcargo carriers. Furthermore, only scheduled operations are studied, which, in contrast to non-scheduled or ad-hoc operations, are set up before the specific demand is known and involve airport decisions that are taken more independently. Based on data available through IATA on scheduled cargo traffic (tonnekilometers) of 2012, we estimated that the scheduled all-cargo traffic excluding traffic by TNT, FedEx and UPS but not by $\mathrm{DHL}^{1}$ covers about $35 \%$ of the worldwide overall air cargo traffic (IATA, 2013). Finally, this study mainly focuses on the choice for origin-destination airports rather than for hub airports. However,

\footnotetext{
${ }^{1}$ As $\mathrm{DHL}$ does not publish data concerning tonne-kilometers, this traffic could not be excluded in the overall share.
} 
also large (cargo) airports like Amsterdam or London Heathrow can be considered non-hub airports for specific airlines which do not offer connecting services at those airports.

In this contribution, we aim to overcome the shortcomings in research concerning airport choice and the airport competition for cargo. We do so by using a stated choice experiment to quantify the importance of the factors driving the airport choice for freighter operations. In Section 2, we present the airport choice process as well as the factors that potentially influence the cargo carriers' choices. In Section 3, we describe the setup of the stated choice experiment, the data collected and the models used for analysis. In Section 4, we present the results of our stated choice analysis. Finally, we discuss the implications of our results for airports and policy makers.

\section{The airport choice process}

A first step towards understanding the way airports and regions compete for scheduled all-cargo services is to outline the process that airlines follow when choosing their airport for cargo operations. In this process, many factors can play a role.

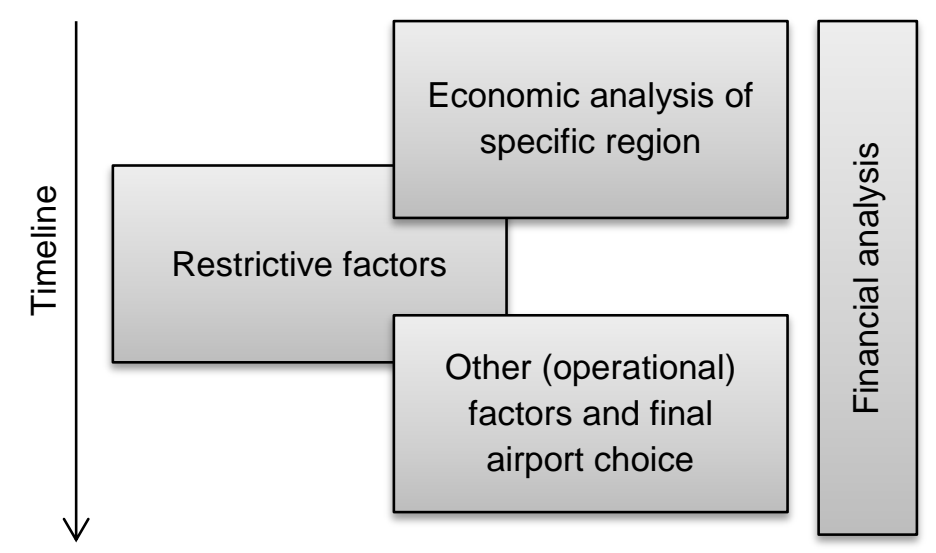

Figure 2 - The airport choice process: findings from discussions with airline representatives

In a previous study by Gardiner (2005a), the airport choice was depicted as a three-stage process: the airline first decides on a region of operation, then analyzes the airports in this region based on possible barriers to operate and finally selects an airport based on its individual merits. However, during formal and informal discussions with airline representatives from Europe, Asia, Africa and the Middle East ${ }^{2}$, it became clear that the process is less hierarchical than outlined by Gardiner (2005a). The three steps of

\footnotetext{
${ }^{2}$ For the discussions and surveys we contacted different types of airlines (combination and all-cargo carriers) and tried to ensure that we had responses from airlines from the different regions. Eventually, we interviewed airlines from Europe, Asia, the Middle East and Africa.
} 
Gardiner (2005a) make up an important part of the airport choice process, but are not always followed consecutively by the airline. The process of the demand analysis (part of economic analysis), the analysis of possible barriers to operate (restrictive factors) and the final selection based on other operational factors often overlap. Therefore, these three parts should be considered as phases of the choice process that may overlap in time, rather than as consecutive steps. In parallel, during the whole airport choice process, different financial analyses are executed on various occasions to check whether serving a region and, later in the process, a particular airport, is financially viable. The course of the airport choice process, as understood after the discussions with airline representatives, is depicted in Figure 2.

\subsection{Economic analysis}

Generally, the economic analysis is the first phase of the airport choice process. Within some airlines, especially larger ones, the economic analysis is even a continuously ongoing process. The aim of the economic analysis is to define the market and the possible demand in a certain region. It can include studies on the general economy of the region as well as of its traffic in goods and trade, as they are often seen as catalysts for air transport (Kupfer et al., 2011). The economic analysis can also include revenue and profitability projections, where yield plays an important role, as well as projections of the inbound and outbound expected demand.

Previous research (see, e.g., Gardiner and Ison (2008)) as well as in-depth interviews showed that, above all, origin-destination demand (demand from the vicinity of the airport and not generated by transit) is one of the most important factors in the economic analysis. This is especially true for non-hub airports as the airlines are especially concerned about minimizing total flight kilometers and costs when choosing their hubs (Zhang, 2003). The government can play an important role in making a region more attractive for air cargo carriers by stimulating the development of industries that rely on air transport, such as biotech industries.

Another factor which plays an important role in the economic analysis and which is closely related to the origin-destination demand is the presence of forwarders at the airport, as this can be an indication of the market size in the area. During the past decades, forwarders evolved from mere agents of airlines to companies that do not only sell air transport services but also coordinate and manage the cargo shipment during its whole transport. Nowadays, forwarders are therefore the main customers of the airlines and hold a central position in the air cargo transport chain. Studies by Rodrigue (2012) and Strale and Bouilla (2012), among others, show that forwarders are often clustered around main cargo airports. As a trend towards consolidation of forwarders can be observed and therefore an increase in their market power, forwarders might even become more important in the airport choice in the future.

\subsection{Restrictive factors}

The restrictive factors considered during the airport choice process are often restrictive from an operational point of view. Some of the most frequently cited restrictive factors are the bilateral 
agreements and traffic rights. Within a region, an airline might not be able to operate from all airports or countries due to traffic right restrictions. Studies by Zhang (2003) and Zhang et al. (2004) show that traffic rights are especially important for the attractiveness of cargo hubs. Such restrictions, however, hinder the airports and regions in their development as well as restrict airlines in their strategies. On the other hand, interviews showed that some airlines do not rely on general bilateral or multilateral agreements for their scheduled operations but rather work on an ad-hoc basis and ask for flight permissions when needed. The government plays an important role in granting these permissions.

Other factors that restrict airlines in using certain airports are noise and night-time restrictions. Noise restrictions especially affect operators that use freighter aircraft, as these aircraft are often older and produce more noise than passenger aircraft. With many airports introducing noise related charges, using freighter aircraft leads to higher costs for airlines. Night-time restrictions are a special case of noise restrictions and specifically concern integrators, as their network operations are based on the nightly transport of packages from airport to airport, mostly via a hub. However, also non-integrated freight operators value night-time slots. In particular on the Asian market, night-time operations at an airport are a must, as the cargo leaves the Asian continent during the night to arrive in Europe the next morning.

At the local level, infrastructure such as warehouse facilities is of utmost importance for airlines and forwarders (Zhang, 2003). Other necessary infrastructure includes sufficient numbers of ramps, parking spaces, runways as well as terminal area (Kingsley-Jones, 2000; Page, 2003). Moreover, the infrastructure is expected to fit the need of air cargo and to be maintained and improved or expanded whenever necessary (Berechman and de Wit, 1996; Hall, 2002).

Another factor that is closely related to infrastructure is capacity. As a matter of fact, capacity restrictions may prevent airlines from flying to specific airports (for instance in the case of London Heathrow which operates at almost $100 \%$ of its runway capacity).

\subsection{Other (operational) factors}

The last phase of the airport choice process is the analysis of other (operational) factors and the choice of an airport itself. In this phase, airlines compare different airports located in a specific region which meet their expectations with regard to (the lack of) restrictions, and finally choose the airport they wish to serve.

There are a myriad of factors influencing the airlines in this phase, such as congestion, airport delays, custom clearance times, turnaround time and the market access. Market access is especially important when the origin-destination demand of one airport cannot compete with the origin-destination demand of another airport. This is often the case for regional airports. One of the competitive advantages of regional airports is congestion free operations on the air- as well as on the landside, which the main airports often cannot offer anymore. This advantage enables airlines to reach the market from regional airports in the same time as they would via congested main airports that are often closer to the market. 
As profit maximization is the ultimate goal of a cargo airline, direct and indirect costs also play an important role in the airlines' decisions. Studies by Berechman and de Wit (1996), among others, reveal that airport charges are important for airlines in their airport choice process. However, also handling and fuel costs, labor costs (next to labor availability) and line-haul costs can play a role.

In their airport choice process, airlines also have to decide whether they want to operate from an airport with passenger operations, competitors and/or partner airlines. To operate from an airport where a partner airline is present can give airlines a competitive advantage due to, for example, the possibility to offer a larger number of destinations from this airport. Operations from the same airport as a competitor, on the other hand, can have disadvantages. Competition in this case might be higher and revenues therefore lower.

Airports usually offer (financial) incentives to attract airlines in order to start services to their airport. However, airlines view incentives as well as airport marketing often only as short-term advantages. In the long run, they consider a good airport reputation and experience with cargo as more important because it reduces uncertainty concerning the quality of collaboration. Sometimes, however, airlines expect incentives to continue and to form a permanent part of their agreement.

Finally, the guarantee of sufficient future capacity, a stable regulatory environment and unfavorable climate conditions such as thick fog, heavy snow or strong winds play a role in the airport choice.

\section{$2.4 \quad$ Financial analysis}

During the three main phases of the airport choice process, airlines perform financial analyses on various occasions to find out whether the service to a certain region or airport is financially viable in the long run. In the starting phase of the airport choice process, the focus of the financial analysis is on the total revenue of the route, with airlines trying to maximize the revenue derived from the origin-destination demand. At the end of the choice process, the focus is more on the direct operating cost, with airlines selecting specific airports for comparison. At this point, airlines try to minimize landing fees, parking and crew costs, etc.

\section{Experimental setup, data and models for data analysis}

\subsection{Selection of the attributes and attribute levels for the stated choice experiment}

In the previous section, we showed that there are numerous factors that influence airlines in their airport choice. Some factors are directly influenced by policy makers (e.g., regulations) or by airports (e.g., airport charges). Inevitably, airlines have to make trade-offs between these factors in their airport choice. 
To better understand how policy makers and airports can influence airlines in their airport choice, a deeper understanding of these trade-offs is needed.

In economics, different valuation methods exist that might give policy makers and airports an idea of the value that airlines attach to the different factors. Examples of such valuation methods are hedonic pricing, contingent valuation, rating-based conjoint analysis and stated and revealed preference analysis. The stated choice approach is the most promising approach as it mimics the choice process best and also enables the researcher to measure the trade-offs that respondents make between the different characteristics of an airport.

Over the years, the number of studies applying the stated choice approach in air transport research and other areas of transport (see, e.g., Ben-Akiva and Lerman (1985) or Rich et al. (2009)) has increased substantially. However, the focus of most studies has been on the airport or airline choice of passenger airlines or passengers (see, e.g., Ashford and Bencheman (1987); Hess and Polak (2010); Ishii et al. (2009); Martín et al. (2008); Wen and Lai (2010)), rather than on the airport choice of cargo airlines.

To fill this void in the literature, we performed a stated choice experiment to model the airport choice of freighter operators. In a first step of the experiment, we identified the potentially most important airport choice factors or attributes and their levels to be used in the experiment. In addition to our literature study described in Section 2, which provided a list of airport attributes, we carried out five exploratory interviews with airlines from Europe, Asia and Africa as well as with airport managers. Those exploratory interviews were semi-structured and included open as well as closed questions on topics such as the airport choice strategy and the importance of the different airport choice factors identified in Section 2. The results of the literature review and the exploratory interviews enabled us to narrow down the attributes and select attribute levels for the stated choice experiment. We selected the following six attributes and attribute levels:

Night-time restrictions

1. Night-time flight prohibitions (prohibitions)

2. Limited or very expensive night-time slots (limited)

3. No night-time restrictions (no restrictions)

\section{Airport experience with cargo}

1. No experience (no)

2. Limited experience (limited)

3. Extended experience (extended) 


\section{Presence of forwarders}

1. No forwarders (no)

2. Only major forwarders (major)

3. Broad range of forwarders (broad range)

\section{Presence of passenger airlines}

1. No passenger airline operations at airport (no)

2. Only passenger operations of own airline/group or of main passenger airline partner (sibling)

3. Different passenger airline operations from own airline/group as well as other airlines (different)

Airport charges (including handling)

1. $20 \%$ higher airport charges $(+20 \%)$

2. $10 \%$ higher airport charges $(+10 \%)$

3. Equal airport charges (equal)

4. $10 \%$ lower airport charges $(-10 \%)$

5. $20 \%$ lower airport charges $(-20 \%)$

\section{Origin-destination demand}

1. $20 \%$ less origin-destination demand $(-20 \%)$

2. $10 \%$ less origin-destination demand $(-10 \%)$

3. Equal origin-destination demand (equal)

4. $10 \%$ more origin-destination demand $(+10 \%)$

5. $20 \%$ more origin-destination demand $(+20 \%)$

Due to the difficulty in getting reference data for origin-destination demand and airport charges that could be used for all airlines, we asked the airlines to compare the airports on origin-destination demand and charges using a benchmark airport of their choice, with an actual difference of up to $40 \%$ between the hypothetical airports. We did not ask the airlines to reveal their benchmark airport with its origindestination demand and charges, because this would have led to confidentiality issues with some airlines and therefore to fewer data. For this reason, we instructed the respondents to choose an airport the airline currently serves as a reference. Therefore, it is reasonable to assume that the benchmark airport is a profitable one.

\subsection{Design of the stated choice experiment}

After selecting the six airport attributes for the stated choice experiment, we designed the stated choice experiment. We presented each respondent with 20 choice situations involving two alternative airports, 
called profiles. For each choice situation, respondents were asked to indicate the profile they preferred. The profiles or alternative airports consist of combinations of levels of the attributes. However, to limit the cognitive burden imposed on the respondents, we showed only four of the six attributes in each choice situation. The resulting profiles are called partial profiles (Green (1974); Kessels et al., (2011a, 2015). We determined the attributes to be shown in every choice situation using the variance-balance partial profile design approach developed for attributes with differing numbers of levels (Kessels et al., 2015). This approach includes the five-level attributes, 'charges' and 'demand', more often than the three-level attributes, to obtain similar amounts of information on each attribute level.

Figure 3 shows an example of a choice situation in which airline representatives had to choose between two hypothetical airports A and B, described by four of the six attributes.

If you had to choose between the following two European airports for full-freighter operations, which one would you choose?

Please choose by clicking one of the buttons below:

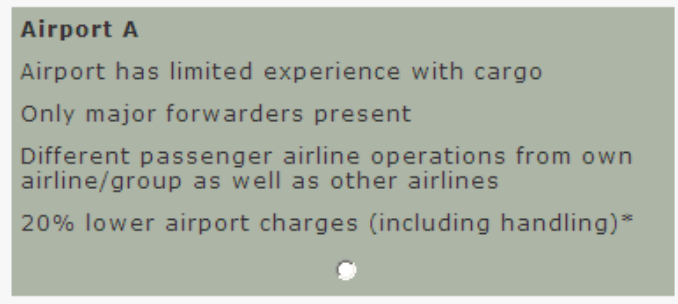

Airport B

Airport has extended experience with cargo

No forwarders present

Only passenger operations of own airline/group or of main passenger airline partner

$10 \%$ lower airport charges (including handling)*

C

* When comparing the O-D demand and the airport charges of the two airports, please use the O-D demand and the airport charges of an airport known to you as a benchmark.

\section{Figure 3 - Example of a choice situation used in the airport choice experiment}

Based on the literature review and our interviews, we expected that origin-destination demand would be a dominating factor in the airlines' choices. Therefore, we generated two different partial profile designs: one six-attribute design including origin-destination demand and one five-attribute design excluding origin-destination demand. Both designs consist of four different blocks or surveys of ten choice sets and can be consulted in Appendix A. For each respondent, we used one block of ten choice situations from the six-attribute design and one block of ten choice situations from the five-attribute design, so that we presented a total of 20 choice situations to every respondent. This way, we ensured that the experiment also yields information concerning the relative importance of the attributes other than origin-destination demand. We randomized the 20 choice situations for each respondent and made sure the four surveys of 20 choice sets were evenly spread over all respondents. Using designs consisting of several surveys results in more precise parameters of the underlying discrete choice model than designs consisting of a single survey (Sándor and Wedel (2005); Kessels et al. (2015)). Furthermore, our partial profile designs take into account prior beliefs about the respondents' preferences. For our experiment, for example, we 
know that respondents prefer no night-time restrictions at an airport to a limited number of available nighttime slots which, in turn, they prefer to night-time flight prohibitions. In Appendix B, we summarize all available information as well as the uncertainty regarding that information in a prior distribution that we used to optimize the designs for the stated choice experiment. The resulting designs are called Bayesian D-optimal designs and are considered the state of the art for stated choice experiments (see, e.g., Bliemer et al. (2008); Rose and Bliemer (2009) and Kessels et al. (2011b); see also Appendix C). One major benefit of Bayesian D-optimal designs is that, using a proper prior distribution, they avoid choice situations in which one profile is dominating the other profile(s) on every attribute (Crabbe and Vandebroek (2012)).

In the final step of the experimental setup, we developed the questionnaire which consists of three parts. In the first part, we collected information about the respondent and the airline. In the second part, we asked the respondents to make choices between hypothetical airports within the framework of the stated choice experiment. Finally, we asked questions about the airport choice strategy of the airline. Before distributing the questionnaire, we sent the questions to a number of representatives from the air cargo sector for pilot testing. We asked the representatives to fill in the questionnaire and communicate all questions and suggestions concerning the understanding and the relevance of the questions. We then incorporated their suggestions in the final questionnaire.

\subsection{Respondents and data}

Between February 2011 and May 2011, we collected a total of 26 completed questionnaires from different airlines. This was done in two ways: through personal interviews and through the internet. Personal interviews give a more in-depth view, especially on the third part of the questionnaire, the airport choice strategy of the airline. Unfortunately, personal interviews could not be carried out for all airlines which is why also an internet-based survey was set up.

Our respondent group of 26 airlines involves more than half of the population of freighter operators with scheduled services to Europe. They serve airports such as Frankfurt, Paris (Orly and Charles de Gaulle), Amsterdam, London (Stansted, Heathrow), Frankfurt-Hahn, Liège, Milan Malpensa, Brussels, Athens, Copenhagen and Basel. For 16 of those 26 airlines, detailed data concerning the tonne-kilometers performed by means of freighters in 2012 was available from IATA World Air Transport Statistics. Those airlines, generally the larger ones in the sample, accounted for about $46.6 \%$ of worldwide all-cargo traffic (expressed in tonne-kilometers) performed in 2012, when including flights from integrators. Moreover, their share amounted to about $68.5 \%$ of worldwide all-cargo traffic, when excluding flights from integrators (calculations based on IATA (2013)).

Because each respondent had to make 20 choices, our dataset contains 520 choices. The 26 respondents involve 11 independent cargo carriers and 15 cargo subsidiaries or cargo divisions of combination carriers. The positions of the respondents within the carriers suggest that the results are 
reliable: the majority of the respondents hold a position that makes them a key decision maker in the airport choice decision process. For example, seven respondents are CEOs or directors of the carrier/subsidiary/division, seven respondents are freighter or planning specialists and five respondents are regional managers for Europe.

\subsection{Models}

We first used the standard multinomial logit (MNL) model to analyze the data from the stated choice experiment. The utility that a respondent attaches to alternative $j(j=1,2)$ in choice situation $s(s=1, \ldots$, 20 ) is then modelled as a sum of a systematic and a stochastic component (Hensher et al. 2005):

$$
U_{j s}=\mathbf{x}_{j s}^{\prime} \boldsymbol{\beta}+\varepsilon_{j s}
$$

In the systematic component $\mathbf{x}_{j s}^{\prime} \boldsymbol{\beta}, \mathbf{x}_{j s}$ is a $k \times 1$ vector containing the coded attribute levels of alternative $j$ in choice situation $s$. In our analysis, we initially assumed that all six attributes are categorical, so that our initial model involved $k=16$ parameters and $\mathbf{x}_{j s}$ and $\boldsymbol{\beta}$ are $16 \times 1$ vectors. The vector $\boldsymbol{\beta}$ is the vector of parameter values indicating the importance of the different attribute levels to the respondents. The stochastic component $\varepsilon_{j s}$ is the error term capturing the unobserved sources of utility. Under the assumption that the error terms are independently and identically Gumbel distributed, the MNL probability that a respondent chooses alternative $j$ in choice situation $s$ is

$$
p_{j s}=\frac{\exp \left(\mathbf{x}_{j s}^{\prime} \boldsymbol{\beta}\right)}{\exp \left(\mathbf{x}_{1 s}^{\prime} \boldsymbol{\beta}\right)+\exp \left(\mathbf{x}_{2 s}^{\prime} \boldsymbol{\beta}\right)}
$$

To estimate the parameter vector $\boldsymbol{\beta}$ in the MNL model, we used a penalized maximum likelihood approach which maximizes the probability of obtaining the responses from the selected data sample using the Firth bias correction (Firth, 1993, 1995). Kessels et al. (2013) adapted Firth's bias-adjustment method for estimating the MNL model and showed that, in the case of small numbers of respondents and a reasonably small number of choices per respondent, this approach results in estimates with a smaller bias and a smaller variance than the estimates obtained using traditional maximum likelihood ${ }^{3}$. We computed the overall significance and the relative importance of the six attributes by means of likelihood ratio (LR) tests. Because of the categorical nature of our attributes and because we used effects-type coding for the attribute levels, the marginal utility values for all but the last level of each attribute correspond to the elements of the vector $\boldsymbol{\beta}$, while the marginal utility for the last level of each attribute is

\footnotetext{
${ }^{3}$ When analyzing our data using the Firth bias correction, the estimates shrank to approximately $96 \%-98 \%$ of the traditional maximum likelihood estimates and the variances to approximately $98 \%-99 \%$ of the variances resulting from the maximum likelihood analysis. This is the shrinkage effect typical of the Firth penalized likelihood approach.
} 
computed as minus the sum of all other marginal utilities for that attribute. We carried out the data analysis for the MNL model using the Choice Modeling platform in the statistical software package JMP, version 10 (SAS Institute, 2010) which uses Firth's penalized maximum likelihood estimation by default. The results of the MNL analysis are discussed in Section 4.1.

In the second phase of the data analysis, we quantified the heterogeneity in the respondents' preferences. We did so in two ways. First, we estimated a panel mixed logit (PML) model, which assumes that every respondent has his/her own preferences for the different attribute levels. The model involves a separate parameter vector $\boldsymbol{\beta}_{i}$ for each respondent $i$. Furthermore, the model assumes that all the individual vectors $\beta_{i}$ are drawn from a normally or uniformly distributed population with a mean preference vector, $\boldsymbol{\beta}$, and a variance-covariance matrix. In contrast with a cross-sectional mixed logit model, a PML model takes into account the heterogeneity between respondents by assuming that the choices made by the same respondent are correlated. We estimated the PML model using the software Biogeme (Bierlaire, 2003), in which we opted for the optimization algorithm DONLOP2 and 2000 pseudo random draws. The results of the PML analysis are reported in Section 4.2.

Because the PML model treats any variation in the individual preferences as random, it does not offer an explanation concerning the origin of the preference heterogeneity. For this reason, we also studied the observed preference heterogeneity by including airline characteristics as covariates in the MNL model. Because the stated choice experiment involved unlabeled alternatives, that is, the alternative airports are not labeled with, for example, the names of real airports, constants in the MNL model are not meaningful (Hensher et al., 2005, p. 373). Therefore, the covariates are included in the model by means of interaction terms with the airport attributes. Due to the limited amount of observations, a covariate PML model could not be estimated. The results of the MNL model analysis including covariate information are discussed in Section 4.3.

\section{Modeling results}

\subsection{Multinomial logit results}

Table 1 shows the initial MNL model that includes all six attributes ranked in order of importance, where the statistical importance of an attribute is measured by - $\log (\mathrm{p}$-value of the LR test), as well as the final MNL model that involves a number of refinements. In the initial MNL model, we treated all attributes as categorical, which enabled us to capture possible nonlinear relationships between the utility of an alternative airport and the attribute levels. In the final MNL model, we retained only the significant attributes and switched from effects-coding to linear coding for the attributes 'airport charges' and 'origindestination demand'. As explained below, this switch of coding was justified according to LR tests for 
these two attributes and implies that we treat the attributes 'airport charges' and 'origin-destination demand' as quantitative explanatory variables in the final MNL model. 
Table 1 - Results of the airport choice MNL modeling

\begin{tabular}{|c|c|c|c|c|c|c|c|c|}
\hline & \multicolumn{4}{|c|}{ Initial MNL model } & \multicolumn{4}{|c|}{ Final MNL model } \\
\hline & $\begin{array}{c}\text { Parameter } \\
\text { estimate }\end{array}$ & $\begin{array}{c}\text { L-R } \\
\text { ChiSquare }\end{array}$ & DF & P-value & $\begin{array}{c}\text { Parameter } \\
\text { estimate }\end{array}$ & $\begin{array}{c}\text { L-R } \\
\text { ChiSquare }\end{array}$ & DF & P-value \\
\hline \multicolumn{9}{|l|}{ Forwarders } \\
\hline no & -1.144 & & & & -1.161 & & & \\
\hline major & 0.412 & 91.954 & 2 & $<0.0001^{*}$ & 0.413 & 92.426 & 2 & $<0.0001^{*}$ \\
\hline broad range & $0.732^{\star *}$ & & & & $0.748^{\star *}$ & & & \\
\hline \multicolumn{9}{|l|}{ Experience } \\
\hline no & -0.412 & & & & -0.416 & & & \\
\hline limited & -0.168 & 27.625 & 2 & $<0.0001^{*}$ & -0.166 & 27.442 & 2 & $<0.0001^{*}$ \\
\hline extended & $0.580^{\star *}$ & & & & $0.582^{\star *}$ & & & \\
\hline \multicolumn{9}{|l|}{ Charges } \\
\hline$+20 \%$ & -0.535 & & & & & & & \\
\hline$+10 \%$ & -0.365 & & & & & & & \\
\hline equal & 0.011 & 28.913 & 4 & $<0.0001^{*}$ & $-0.029^{\mathrm{LC}}$ & 28.094 & 1 & $<0.0001^{*}$ \\
\hline$-10 \%$ & 0.370 & & & & & & & \\
\hline$-20 \%$ & $0.519^{\star \star}$ & & & & & & & \\
\hline \multicolumn{9}{|l|}{ Demand } \\
\hline$-20 \%$ & -0.578 & & & & & & & \\
\hline$-10 \%$ & -0.374 & & & & & & & \\
\hline equal & 0.007 & 13.396 & 4 & $0.0095^{\star}$ & $0.032^{\mathrm{LC}}$ & 13.308 & 1 & $0.0003^{*}$ \\
\hline$+10 \%$ & 0.273 & & & & & & & \\
\hline$+20 \%$ & $0.672^{\star *}$ & & & & & & & \\
\hline \multicolumn{9}{|l|}{ Night-time } \\
\hline prohibitions & -0.275 & & & & -0.289 & & & \\
\hline limited & 0.009 & 6.291 & 2 & $0.0430^{*}$ & 0.016 & 6.609 & 2 & $0.0367^{*}$ \\
\hline no restrictions & $0.266^{\star \star}$ & & & & $0.273^{\star \star}$ & & & \\
\hline \multicolumn{9}{|l|}{ Passenger } \\
\hline no & -0.106 & & & & & & & \\
\hline sibling & -0.085 & 3.761 & 2 & 0.1525 & & & & \\
\hline different & $0.191^{\star \star}$ & & & & & & & \\
\hline LogLikelihood & & -302.634 & & & & -304.955 & & \\
\hline
\end{tabular}

* Significant at $5 \%$ level

** Marginal utility values corresponding to the last level of each effects-coded attribute are indicated in italic to stress that they are calculated as minus the sum of all other marginal utility values of that attribute.

LC Linear coefficient

For the initial and the final MNL model, Table 1 shows the parameter estimates or marginal utility values of the attribute levels and the significances of the attributes' effects as produced by LR tests. For the initial MNL model, the LR tests indicate that all attributes are significant at the $5 \%$ level except for 
'passenger operations'. This means that, for scheduled freighter operations, airlines are indifferent between airports with passenger operations and airports without, when choosing which airport to serve. Even when estimating MNL models for all-cargo carriers and combination carriers separately, the attribute 'passenger operations' remains insignificant for both types of airlines. For all-cargo carriers, that does not seem surprising as there is no strong link between all-cargo carriers and passenger operations. For combination carriers, the insignificance of 'passenger operations', however, might seem counter-intuitive and partly contradicts Gardiner and Ison (2008), who observed that, for those carriers, an airport is more attractive when it also has passenger operations. The insignificance of the attribute 'passenger operations' might, however, be explained by the scope of our study which only covers freighter operations, which are by nature less related to passenger operations than the transport of air cargo in passenger aircraft. Our result that passenger operations do not influence the attractiveness of an airport also has policy implications because, from an airline point of view, it supports the idea of cargo-only airports. Therefore, when governments have to deal with congestion at a main airport, relocating freighter operations is an option at first glance. However, since air freight is not only transported in freighters but also in the belly of a passenger aircraft, the viability of an all-cargo airport depends on the total volume of freighter traffic it can attract and whether this will suffice to cover the costs of the airport.

Figure 4 shows the statistical importance of the five attributes in the final MNL model relative to the importance of the attribute 'presence of forwarders', which is the most important attribute for the airlines when choosing an airport for freighter operations in Europe. The second most important attribute is the experience of an airport with cargo, followed by the airport charges, origin-destination demand and nighttime restrictions. As mentioned in Section 3, prior to the experiment, we expected origin-destination demand to be the most important attribute of airport choice. Therefore, we constructed one six-attribute choice design including the attribute demand and another five-attribute design excluding it. To assess whether this design strategy had an influence on the importance ranking of the attributes, we estimated two separate MNL models. For one MNL model, we used the observations produced by the six-attribute design including demand, and, for the other MNL model, we used the observations produced by the fiveattribute design excluding demand. In both models, the importance ranking of the different attributes is similar to that obtained by pooling the data and estimating a single MNL model. Therefore, the decision to generate two different choice designs and to pool the associated data for the estimation of a single MNL model did not have an influence on the importance ranking of the attributes. 


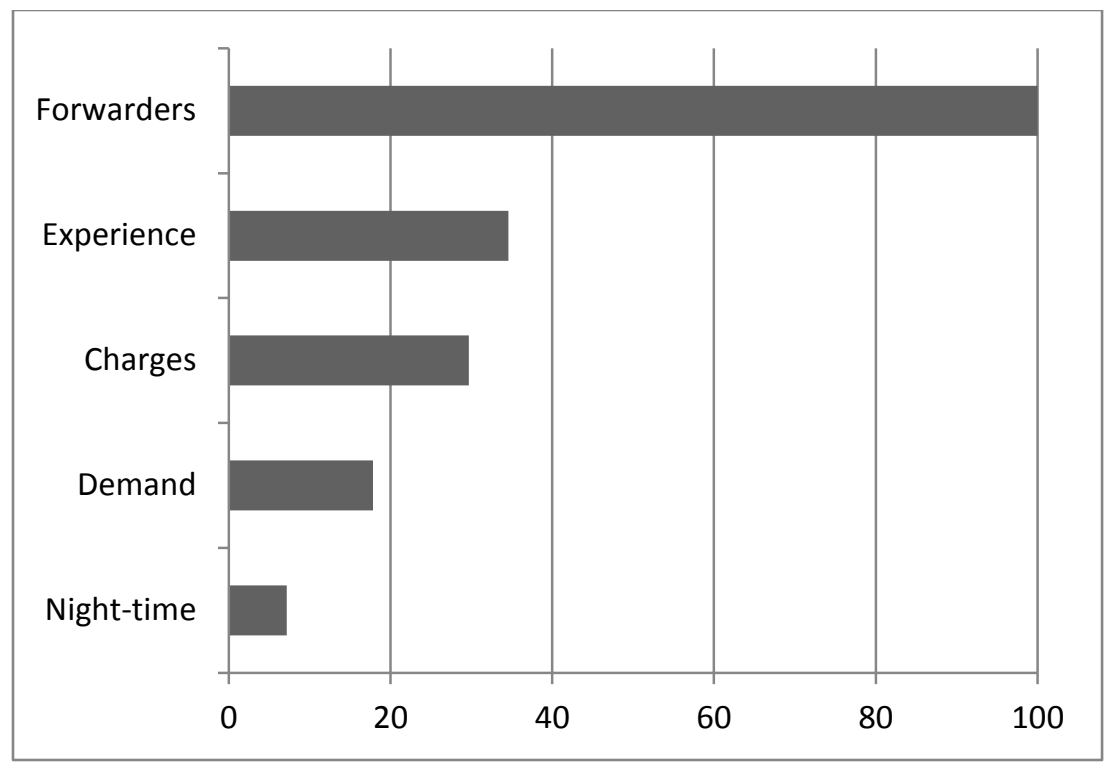

Figure 4 - Statistical importance of the five attributes in the final MNL model relative to the most important attribute, 'presence of forwarders'

For the construction of the final MNL model, we excluded the insignificant attribute 'passenger operations', and examined whether the effects of the attributes 'airport charges' and 'origin-destination demand' on an airport's relative utility could be linearized. Figure 5 and Figure 6 show the marginal utilities or parameter estimates obtained from both nonlinear or effects-type coding and linear coding for the attributes 'airport charges' and 'origin-destination demand', respectively. It is clear that assuming linear relationships for the two attributes is reasonable, and that switching from effects-type coding to linear coding is justified. This was confirmed by a LR test, which indicated that the nonlinear specifications of the attributes did not add to the statistical fit of the MNL model ( $L-R$ ChiSquare $=0.88$; $\mathrm{DF}=6 ; \mathrm{p}$-value $=0.99)$. As a result, our final MNL model contains linear parameter estimates for the attributes 'airport charges' and 'origin-destination demand'. A total of $71 \%$ (369 out of 520) of the respondents' choices could be predicted correctly using this model. 


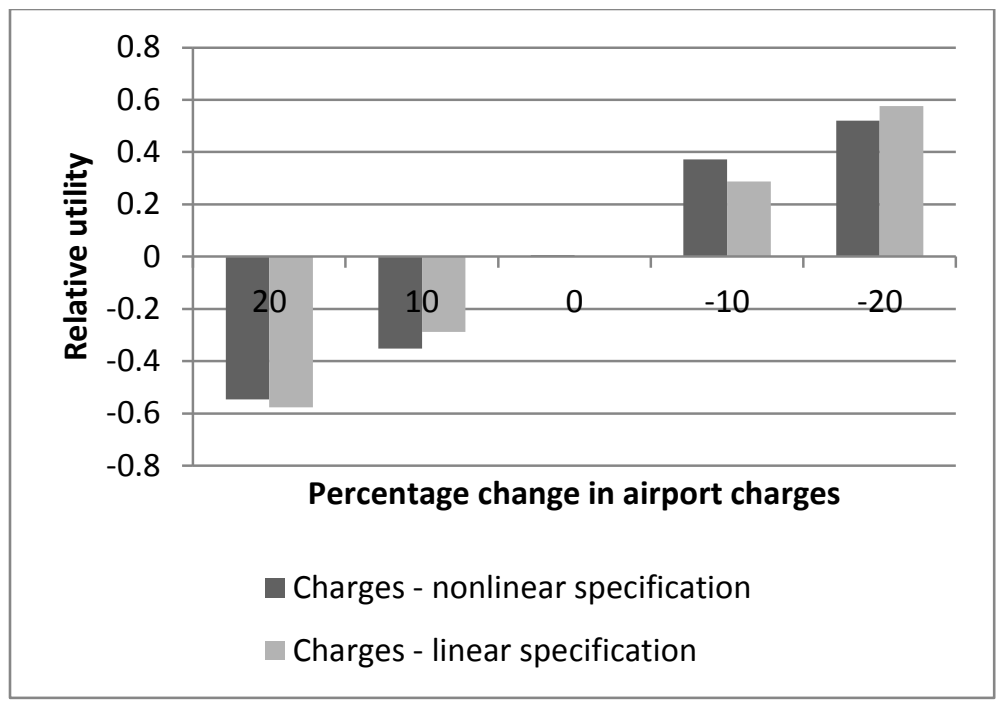

Figure 5 - Marginal utilities of airport charges, obtained using nonlinear and linear coding

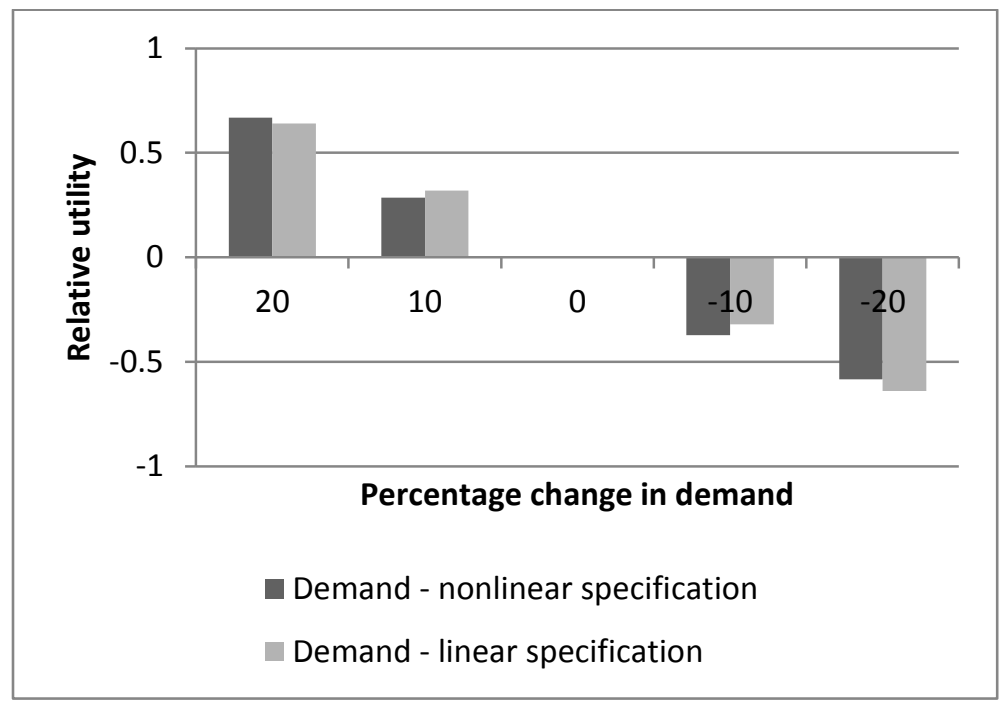

Figure 6 - Marginal utilities of demand, obtained using nonlinear and linear coding

Finally, Table 1 shows that the parameter estimates for the attributes 'presence of forwarders', 'experience with cargo' and 'night-time restrictions' in the final MNL model do not differ much from those in the initial MNL model. The signs of the parameter estimates are as expected. For example, they are negative for night-time flight prohibitions and the absence of forwarders at an airport, and positive for no night-time restrictions and extended experience with cargo.

It can be seen that the largest difference in relative utility is realized between having no forwarders at an airport and having only the major forwarders. This means that an airport without forwarders is much less attractive than an airport with the major forwarders only. This is not very surprising given the importance 
of forwarders in the air cargo sector nowadays. However, a few years ago, some regional airports such as Liège International Airport were quite successful without having many forwarders stationed at or around the airport. ${ }^{4}$ Nowadays though, also those airports focus on attracting forwarders. The one but largest difference in relative utility is the one between limited experience with cargo and extended experience with cargo. Furthermore, the difference in relative utility between limited experience with cargo and no experience with cargo is rather small, showing that airlines do not make a clear distinction between airports with limited experience with cargo and airports lacking such experience.

\subsection{Taking into account the heterogeneity in airlines' preferences}

To express airlines' heterogeneity in their airport choices, we estimated a panel mixed logit (PML) model as well as a MNL model with covariate information, henceforth referred to as a covariate MNL model.

\subsubsection{Panel mixed logit model}

Table 2 shows the initial PML model that includes all six attributes ranked in order of importance, as well as the final PML model, in which we made a number of refinements. In the initial PML model, we assumed all parameters to be randomly distributed. For the PML analysis reported here, we assumed uniformly distributed parameters for the effects-coded attributes, which is considered to be best practice for effects-coded variables (Hensher et al., 2005, p. 612). For comparison, we also carried out the PML analysis assuming normally distributed parameters for the effects-coded attributes. This did not yield substantially different results. For the linearly coded attributes 'airport charges' and 'demand', we used normally distributed parameters. As in the MNL analysis, the only attribute which turned out to be insignificant was 'passenger operations'.

\footnotetext{
${ }^{4}$ For this reason, we included the attribute level 'forwarders - no' in our study, expressing that there are no forwarders present at the airport of choice.
} 
Table 2 - Results of the airport choice PML modeling

\begin{tabular}{|c|c|c|c|c|c|c|c|c|}
\hline & \multicolumn{4}{|c|}{ Initial PML model } & \multicolumn{4}{|c|}{ Final PML model } \\
\hline & $\begin{array}{c}\text { Parameter } \\
\text { estimate } \\
\text { (std } \\
\text { deviation) }\end{array}$ & $\begin{array}{c}\text { L-R } \\
\text { ChiSquare }\end{array}$ & DF & P-value & $\begin{array}{c}\text { Parameter } \\
\text { estimate } \\
\text { (std } \\
\text { deviation) } \\
\end{array}$ & $\begin{array}{c}\text { L-R } \\
\text { ChiSquare }\end{array}$ & DF & P-value \\
\hline \multicolumn{9}{|l|}{ Forwarders } \\
\hline $\begin{array}{r}\text { no } \\
\text { major } \\
\text { broad range }\end{array}$ & $\begin{array}{c}-2.66 \\
(2.87) \\
0.935 \\
(1.17) \\
1.73 \\
(1.60) \\
\end{array}$ & 123.620 & 4 & $<0.0001^{*}$ & $\begin{array}{c}-2.21 \\
(2.40) \\
0.734 \\
(0.924) \\
1.48 \\
(1.56) \\
\end{array}$ & 126.332 & 4 & $<0.0001^{*}$ \\
\hline \multicolumn{9}{|l|}{ Experience } \\
\hline $\begin{array}{r}\text { no } \\
\text { limited } \\
\text { extended }\end{array}$ & $\begin{array}{c}-0.821 \\
(1.31) \\
-0.159 \\
(0.850) \\
0.98 \\
(1.43) \\
\end{array}$ & 41.096 & 4 & $<0.0001^{*}$ & $\begin{array}{c}-0.688 \\
(1.20) \\
-0.170 \\
(0.420) \\
0.86 \\
(1.31)\end{array}$ & 37.600 & 4 & $<0.0001^{*}$ \\
\hline \multicolumn{9}{|l|}{ Demand } \\
\hline & $\begin{array}{c}0.0858^{\mathrm{LC}} \\
(0.102)\end{array}$ & 39.308 & 2 & $<0.0001^{*}$ & $\begin{array}{l}0.0646^{\mathrm{LC}} \\
(0.0838)\end{array}$ & 36.304 & 2 & $<0.0001^{*}$ \\
\hline \multicolumn{9}{|l|}{ Charges } \\
\hline & $\begin{array}{c}-0.0525^{\mathrm{LC}} \\
(0.0335)\end{array}$ & 34.082 & 2 & $<0.0001^{*}$ & $-0.0471^{\text {LC }}$ & 28.828 & 1 & $<0.0001^{*}$ \\
\hline \multicolumn{9}{|l|}{ Night-time } \\
\hline $\begin{array}{l}\text { prohibitions } \\
\text { limited } \\
\text { no restrictions }\end{array}$ & $\begin{array}{c}-0.950 \\
(2.22) \\
-0.131 \\
(0.752) \\
1.08 \\
(1.53) \\
\end{array}$ & 33.140 & 4 & $<0.0001^{*}$ & $\begin{array}{c}-0.734 \\
(1.83) \\
-0.0661 \\
(0.508) \\
0.80 \\
(1.43)\end{array}$ & 37.398 & 4 & $<0.0001^{*}$ \\
\hline \multicolumn{9}{|l|}{ Passenger } \\
\hline $\begin{array}{r}\text { no } \\
\text { sibling } \\
\text { different }\end{array}$ & $\begin{array}{c}-0.250 \\
(0.646) \\
-0.0598 \\
(0.375) \\
0.31 \\
(1.17)\end{array}$ & 4.952 & 4 & 0.292 & & & & \\
\hline LogLikelihood & & -253.551 & & & & -256.909 & & \\
\hline
\end{tabular}

* Significant at $5 \%$ level

** Parameter estimates and standard deviations corresponding to the last level of each effects-coded attribute are indicated in italic to stress that they are calculated from the other estimates corresponding to that attribute.

${ }^{L C}$ Linear coefficient 
The parameter estimates of Table 2 from the PML analysis differ from those of Table 1 from the MNL analysis. This is mainly due to the large amount of preference heterogeneity between the airlines (cfr. below).

In the final PML model, we excluded 'passenger operations'. The LR tests for the significance of the parameter estimates as well as the parameters' standard deviation showed that all of these are significant at the $5 \%$ level, except for the standard deviation of the parameter estimate for 'airport charges' (L-R ChiSquare $=1.764 ; \mathrm{DF}=1 ; \mathrm{p}$-value $=0.18$ ). Therefore, in the final PML model, we did not treat the linear coefficient of airport charges as random. This decision was supported by interviews with the airlines which showed that there was little disagreement between airlines concerning the importance of airport charges.

Figure 7 shows the statistical importance of the attributes in the final PML model relative to the most important attribute, 'presence of forwarders', which we also found to be most important in the MNL analysis. We see that the importances of the attributes 'demand', 'charges', 'experience' and 'night-time restrictions' are relatively close to each other.

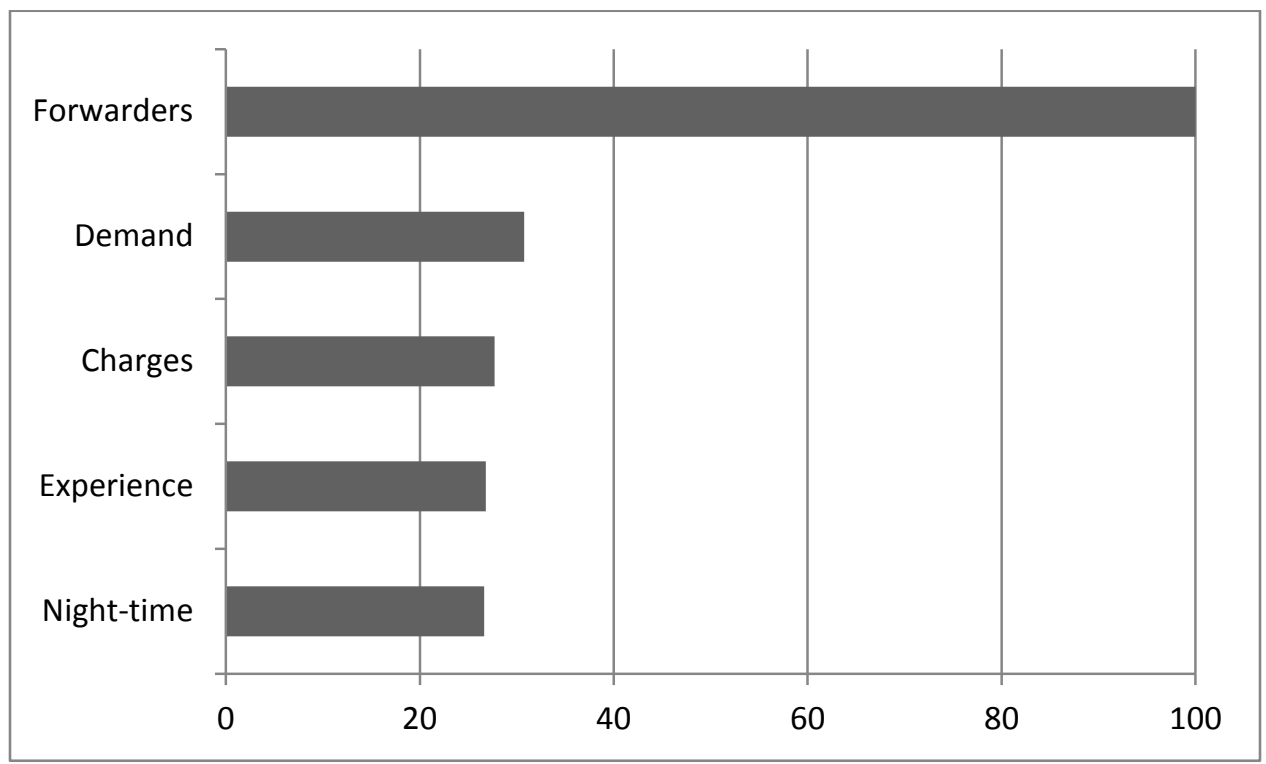

Figure 7 - Statistical importance of the five attributes in the final PML model relative to the most important attribute 'presence of forwarders'

In the final PML model, we tested the significance of the parameters' standard deviation as shown in Table 3. The standard deviations of the parameter estimates for 'presence of forwarders' turned out to have the strongest significance. This supports the idea that there are differences in how important the presence of forwarders at an airport is for airlines. In other words, some airlines find the presence of forwarders crucial, while others are also willing to serve airports without forwarders. The LR tests also reveal strongly significant standard deviations for night-time restrictions. Therefore, also this attribute is judged differently by the various airlines. Some airlines, for example, are able to work around night-time 
restrictions, while others need the possibility to carry out night-time flights in order to optimize their operations.

Table 3 - LR tests of the parameters' standard deviations

\begin{tabular}{|l|ccc|}
\hline & L-R ChiSquare & DF & P-value \\
\hline Forwarders & 32.054 & 2 & $<0.0001$ \\
Night-time & 26.424 & 2 & $<0.0001$ \\
Demand & 13.238 & 1 & 0.0003 \\
Experience & 9.638 & 2 & 0.0080 \\
\hline
\end{tabular}

Furthermore, also the standard deviations of the parameters for the attributes 'demand' and 'experience' turned out to be significant. The standard deviations for demand can be traced back to the decisions of the airlines to organize some of the trucking themselves (as a result of which the origin-destination demand is of less importance) or to only provide airport to airport transport. The standard deviation for airport experience can be ascribed to the differences between smaller and larger airlines. Larger airlines often have the capability and financial possibility to send their employees to a new airport to collaborate with the airport and to train and advise the airport staff as well as to share their experience. Furthermore, they are able to provide some airport services, such as handling, themselves. As a result, they are not dependent on the experience of the airport with cargo. Smaller airlines often do not have that possibility and, hence, they are dependent on the experience of the airport.

\subsubsection{Covariate MNL model}

The results of the PML analysis showed that the airlines are heterogeneous in their preferences. In the final PML model, we observed large standard deviations for 'presence of forwarders', 'night-time restrictions' and 'experience with cargo'. Therefore, the question arises whether these standard deviations between the airlines describe purely random preference heterogeneity or whether they can be explained by the airlines' properties. To deal with that question, we incorporate different airline characteristics into the MNL model analysis.

We used two covariates to reflect the differences in airlines and included them in the MNL model analysis by means of interaction terms with the airport attributes. The first covariate, 'main airport', takes two levels and expresses whether the airline serves major airports (yes) such as Brussels, Paris etc. or regional airports (no) such as Liège and Frankfurt-Hahn. The aim of studying this covariate was to examine whether airlines that serve major airports value the various airport attributes in a different way than airlines that serve regional airports. The second covariate, 'full cargo', also takes two levels and expresses whether the airline is a full cargo airline (yes) or part of a combination carrier (no). It was included in the analysis to find out whether full cargo airlines value the attributes differently than divisions or subsidiaries of combination carriers. 
Table 4 - Covariate MNL model

\begin{tabular}{|c|c|c|c|c|c|}
\hline & $\begin{array}{l}\text { Parameter } \\
\text { estimate }\end{array}$ & $\begin{array}{l}\text { Marginal } \\
\text { utility }\end{array}$ & $\begin{array}{c}\text { L-R } \\
\text { ChiSquare }\end{array}$ & DF & P-value \\
\hline \multicolumn{6}{|c|}{ Night-time*main airport } \\
\hline no restriction, no & 0.921 & 1.947 & \multirow{6}{*}{46.820} & \multirow{6}{*}{2} & \multirow{6}{*}{$<0.0001^{*}$} \\
\hline no restriction, yes & -0.921 & 0.105 & & & \\
\hline limited, no & -0.022 & 0.005 & & & \\
\hline limited, yes & 0.022 & 0.050 & & & \\
\hline prohibitions, no & -0.899 & -1.838 & & & \\
\hline prohibitions, yes & 0.899 & -0.040 & & & \\
\hline \multicolumn{6}{|l|}{ Night-time } \\
\hline prohibitions & -0.977 & -0.977 & \multirow{3}{*}{41.044} & \multirow{3}{*}{2} & \multirow{3}{*}{$<0.0001^{*}$} \\
\hline limited & -0.010 & -0.010 & & & \\
\hline no restrictions & 0.988 & 0.988 & & & \\
\hline \multicolumn{6}{|c|}{ Forwardersmain airport } \\
\hline broad range, no & -0.292 & 0.451 & \multirow{6}{*}{33.763} & \multirow{6}{*}{2} & \multirow{6}{*}{$<0.0001^{*}$} \\
\hline broad range, yes & 0.292 & 1.034 & & & \\
\hline major, no & -0.472 & -0.261 & & & \\
\hline major, yes & 0.472 & 0.683 & & & \\
\hline no, no & 0.764 & -0.075 & & & \\
\hline no, yes & -0.764 & -1.603 & & & \\
\hline \multicolumn{6}{|l|}{ Charges } \\
\hline & $-0.034^{\mathrm{LC}}$ & -0.034 & 32.386 & 1 & $<0.0001^{*}$ \\
\hline \multicolumn{6}{|l|}{ Forwarders } \\
\hline broad range & 0.704 & 0.704 & \multirow{3}{*}{31.910} & \multirow{3}{*}{2} & \multirow{3}{*}{$<0.0001^{*}$} \\
\hline major & 0.173 & 0.173 & & & \\
\hline no & -0.877 & -0.877 & & & \\
\hline \multicolumn{6}{|l|}{ Experience } \\
\hline extended & 0.663 & 0.663 & \multirow{3}{*}{31.904} & \multirow{3}{*}{2} & \multirow{3}{*}{$<0.0001^{*}$} \\
\hline limited & -0.160 & -0.160 & & & \\
\hline no & -0.502 & -0.502 & & & \\
\hline \multicolumn{6}{|l|}{ Demand } \\
\hline & $0.040^{\text {LC }}$ & 0.040 & 18.083 & 1 & $<0.0001^{*}$ \\
\hline LogLikelihood & & & -262.317 & & \\
\hline
\end{tabular}

* Significant at $5 \%$ level

** Parameter estimates of each effects-coded attribute indicated in italic are calculated as minus the sum of all other parameter estimates of that attribute.

LC Linear coefficient

We also considered including interaction terms with the size of the airline (tonnekilometers, tonnes or revenue). Unfortunately, for some airlines information, on their all-cargo traffic or financial information concerning only the cargo operations was lacking. However, for various reasons, such as less 
competition and more flexibility, smaller airlines generally prefer regional airports, while bigger airlines often prefer main airports. As a result, the size of airlines is, to a large extent, reflected in the kinds of airports they serve, as measured by our first covariate 'main airport'.

First, we estimated a model with the five main airport attributes and all possible interactions with the covariates 'main airport' and 'full cargo'. We found, for example, that none of the interactions involving the distinction between full cargo airlines and airlines that are part of a combination carrier were significant. Table 4 shows the results of the covariate MNL model which we found after dropping all insignificant model terms one by one.

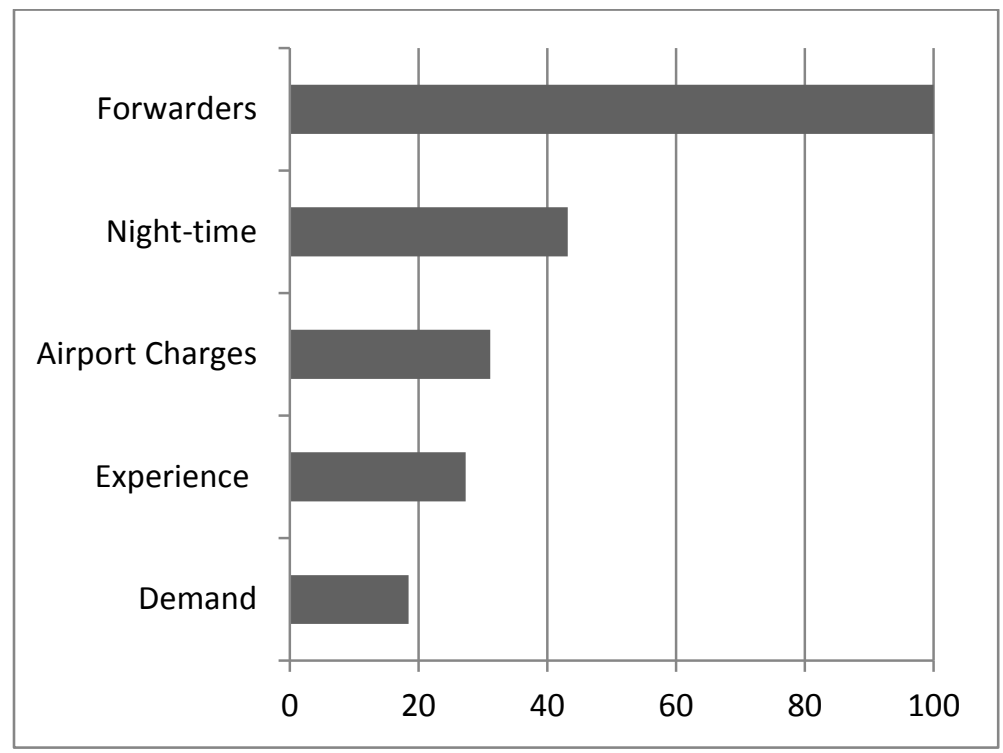

Figure 8 - Statistical importance of the five main attributes in the covariate MNL model relative to the most important attribute 'presence of forwarders'

As in the final MNL and final PML models, overall, the presence of forwarders is the most important attribute when choosing an airport (see Figure 8). It is noteworthy that, when taking into account the differences between airlines, the second most important attribute is night-time restrictions. Night-time restrictions were also found to be significant in the final MNL and PML models. However, in those models, they turned out to be less important than most of the other attributes. The covariate MNL model is not only more realistic than the final MNL model because it acknowledges differences between airlines, but the high importance of night-time flights in that model is actually much more in line with the results of previous studies (see Gardiner et al. (2005b)). As in the final MNL model, in the covariate MNL model, the demand turned out to be less important than the other airport attributes. However, there might be some interdependence between the presence of forwarders and the origin-destination demand. Forwarders are the main customers of the airlines. Furthermore, forwarders often consolidate the freight before bringing them to the airlines after discovering (potential) markets. Therefore, airlines, who are interested in the potential market, might interpret forwarders as an indicator of potential demand. As expected, there are 
differences in preference between the airlines concerning the presence of forwarders as are many forwarders are present in the vicinity of main airports, whereas none or few are present in the vicinity of regional airports.

Figure 9 shows the differences in marginal utilities of night-time restrictions between airlines that serve main airports and airlines that serve regional airports. We can see a large difference in the marginal utility for no night-time restrictions at the airport and night-time flight prohibition for carriers who fly to regional airports. So, for these carriers, the lack of night-time restrictions is very important. Therefore, the marginal utility of having no restrictions is much higher for carriers that fly to regional airports than for those who serve main airports. That means that the absence of night-time restrictions at an airport has a much larger impact on the probability of an airport being chosen for carriers that generally fly to regional airports than for carriers flying to main airports. For night-time flight prohibitions, we observe that an airport with nighttime flight prohibitions is much less interesting for an airline that mainly serves regional airports than for an airline that generally flies to main airports.

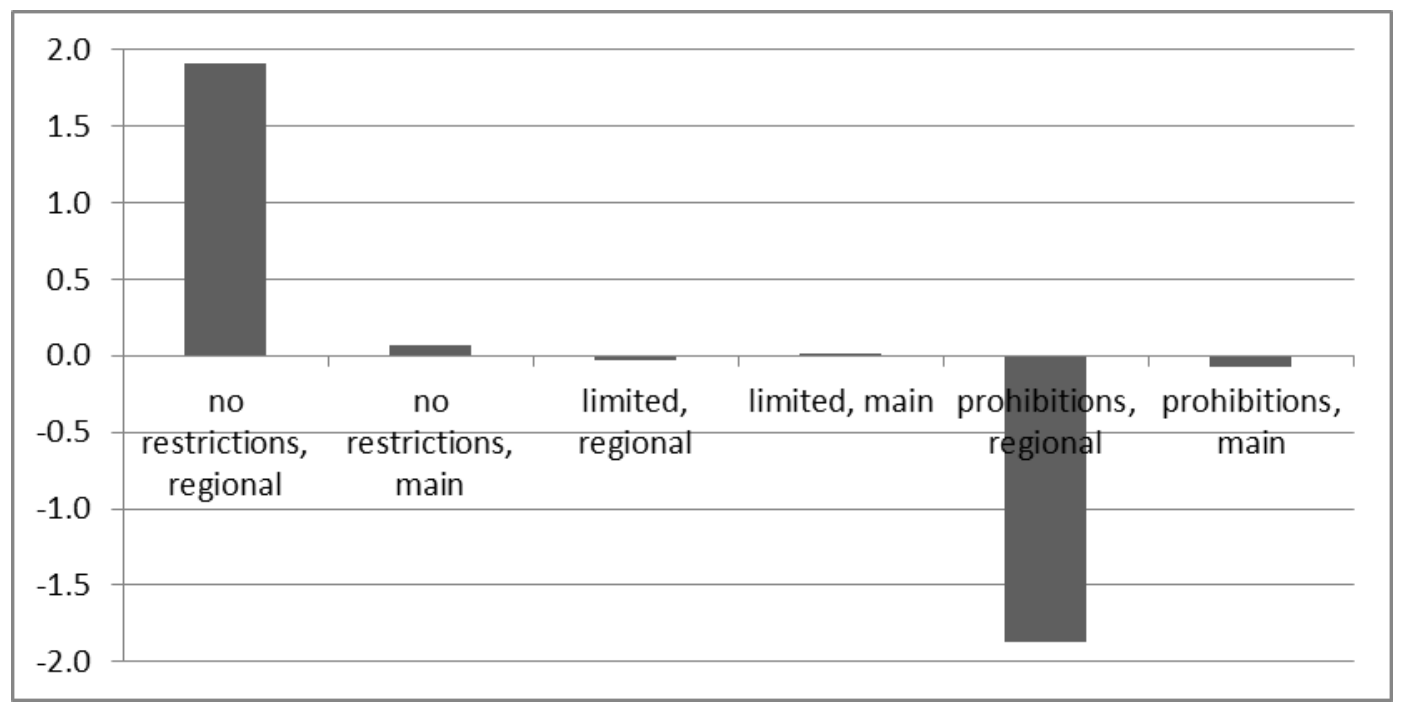

Figure 9 - Marginal utilities of the levels of the attribute 'night-time restrictions' for airlines that serve regional airports and airlines that serve main airports

We can also observe large differences in the marginal utilities between the two types of carriers concerning the presence of forwarders (see Figure 10). The biggest difference between the airlines occurs for the marginal utilities of no forwarders present at the airport. The marginal utility of having no forwarders at the airport is much smaller for carriers that fly to main airports than for carriers serving regional airports. The former airlines therefore find the absence of forwarders much less acceptable than airlines that fly mainly to regional airports. We were able to confirm this during an interview with an airline flying to regional airports. The employee of this airline, for example, explained that he does not necessarily need face-to-face contact with forwarders but relies much more on contact by phone or email. 
For airlines that mainly serve regional airports, the presence of only major forwarders at an airport is not considered valuable, while airlines that serve main airports do consider the presence of only major forwarders valuable. This might be explained by the fact that airlines that serve regional airports are often smaller airlines, which depend more on short term and ad-hoc assignments. Major forwarders frequently have long-term contracts with specific and often bigger airlines, which is why their presence is considered less important for smaller airlines. We were able to confirm this I during interviews with airlines as well.

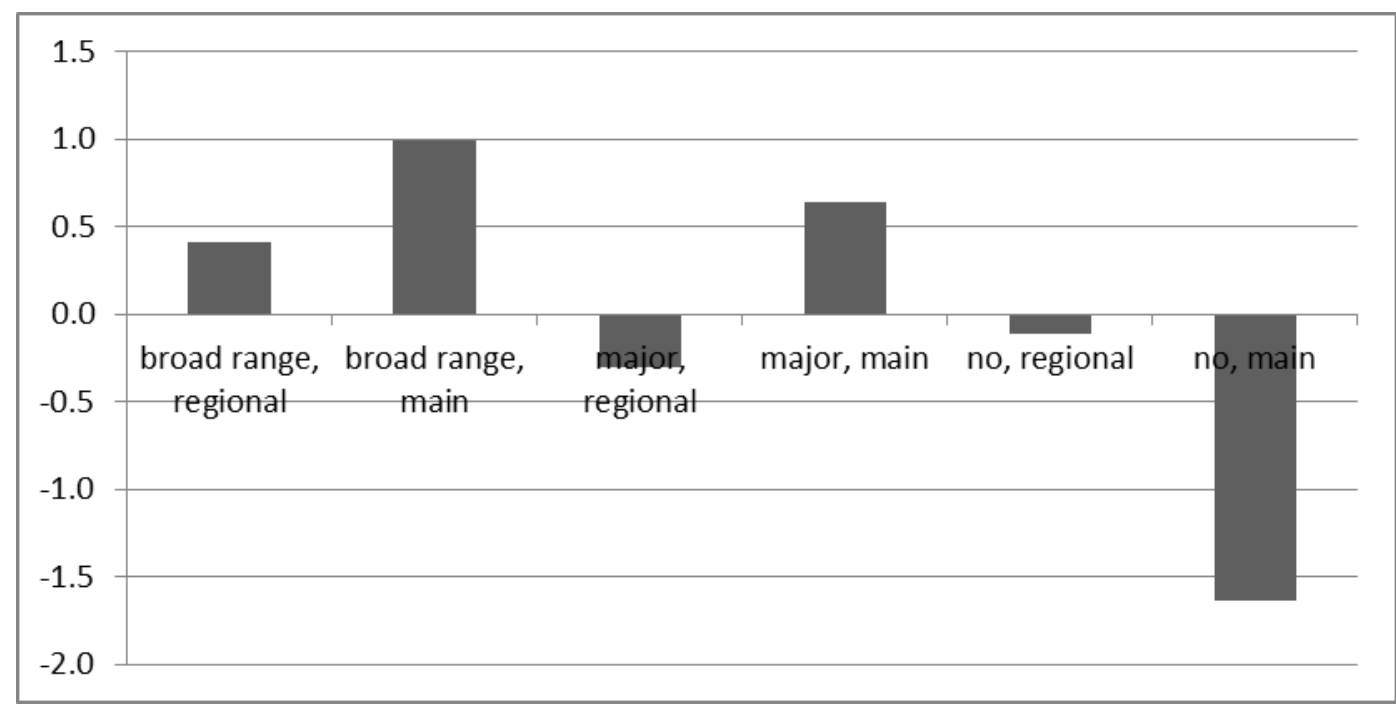

Figure 10 - Marginal utilities of the levels of the attribute 'presence of forwarders' for airlines that serve regional airports and airlines that serve main airports

\subsection{Compensation indices}

An interesting feature of discrete choice analysis is the possibility to calculate willingness to pay estimates. These measurements can provide more information on the monetary value of the attributes under study. Unfortunately, willingness to pay measurements require at least one attribute to be specified in monetary terms, which was not possible in our stated choice experiment. As a matter of fact, for reasons of confidentiality, we expressed the levels of the attributes 'demand' and 'airport charges' in percentage changes rather than in monetary terms.

Nevertheless, we were able to calculate selected compensation indices $(\mathrm{Cl})$, which, just like willingness to pay estimates, provide decision makers and airports with an idea about the specific value of an attribute and trade-offs between attributes. Such compensation indices can be found in Danielis et al. (2005), amongst others. 
Compensation indices are calculated in a fashion similar to willingness to pay ratios:

$\mathrm{CI}_{\mathrm{xc}}=-\frac{\Delta \mathrm{U}_{\mathrm{x}}}{\Delta \mathrm{U}_{\mathrm{c}}}$,

where

$\Delta \mathrm{U}_{\mathrm{x}}$ is the change in utility when modifying the level of an attribute $\mathrm{x}$, and $\Delta \mathrm{U}_{\mathrm{c}}$ is the change in utility due to a $1 \%$ change in airport charges or demand.

This means that we calculated the compensation indices by taking either the changes in airport charges or in demand as basis. The compensation indices computed for airport charges show how large the difference in airport charges has to be between two airports when changing the level of one of the categorical attributes, so that the airports possess the same relative utility (and therefore the same relative attractiveness). In other words, they show what increase in airport charges an airline is willing to accept in exchange for an improvement in the level of another attribute, or what decrease in airport charges needs to be offered in exchange for a deterioration of the level of another attribute. The meaning of the compensation indices for demand is similar.

Table 5 - Compensation indices based on the final MNL and PML model

\begin{tabular}{|l|cc|cc|}
\hline & \multicolumn{2}{|c|}{$\begin{array}{c}\text { Airport charges - } \\
\text { compensation indices }\end{array}$} & \multicolumn{2}{c|}{$\begin{array}{c}\text { Demand - } \\
\text { compensation indices }\end{array}$} \\
\hline & $\begin{array}{c}\text { Final MNL } \\
\text { model }\end{array}$ & $\begin{array}{c}\text { Final PML } \\
\text { model }\end{array}$ & $\begin{array}{c}\text { Final MNL } \\
\text { model }\end{array}$ & $\begin{array}{c}\text { Final PML } \\
\text { model }\end{array}$ \\
\hline $\begin{array}{l}\text { From/to level } \\
\text { Night-time }\end{array}$ & & & & \\
\hline no restrictions - limited & -8.9 & -18.4 & 8.0 & 1.3 \\
limited - prohibitions & -10.5 & -14.2 & 9.5 & 1.0 \\
no restrictions - prohibitions & -19.4 & -32.7 & 17.6 & 2.3 \\
\hline Experience & & & & 1.6 \\
\hline extended - limited & -25.8 & -21.9 & 23.4 & 0.8 \\
limited - no & -8.6 & -11.0 & 7.8 & 2.4 \\
extended - no & -34.4 & -32.9 & 31.2 & 1.2 \\
\hline Forwarders & & & & 4.6 \\
\hline broad range - major & -11.6 & -15.8 & 10.5 & 5.7 \\
major - no & -54.3 & -62.5 & 49.2 & \\
broad range - no & -65.9 & -78.3 & 59.7 & \\
\hline
\end{tabular}

We decided to build indices based on the final MNL and PML models as they respectively give a general as well as more differentiated indication of the trade-offs that airlines are willing to make. We can see in Table 5 that the airport charges compensation indices based on the MNL and PML model are similar. However, we identified some differences concerning the demand - compensation indices. First, those differences can be attributed to the taste-heterogeneity of the airlines. Moreover, the largest differences between the indices occur for the attributes forwarders and experience for which airlines have particularly heterogeneous preferences (see Section 4.2.2.) Second, the PML model confronts us with a limitation. For the compensation indices of demand, both numerator and denominator are random variables with a 
uniform or normal distribution. The resulting compensation indices have an unknown variation, standard deviation and mean. With a limited number of respondents, in our case 26 respondents, the results might be less stable. On the other hand, for the compensation indices of airport charges, because this attribute is not treated as random in the final PML model, the compensation indices computed for the latter model are comparable to those based on the final MNL model.

The largest compensation index can be found when comparing an airport without forwarders to an airport with a broad range of forwarders. Based on the PML model, to have the same attractiveness, the airport charges at an airport without forwarders would have to be more than $78 \%$ lower than at an airport with major forwarders. The compensation index based on the final MNL model provides similar results. The large compensation indices once more show the importance of the presence of forwarders at an airport.

Another large compensation index can be found for an airport with extended experience with cargo and one without any experience. Based on the MNL model, in order to bridge this difference, a change of more than $34 \%$ in airport charges or more than $31 \%$ in demand is needed.

Concerning night-time restrictions, we can see that an airport with limited night-time flights would have to offer an airline 9 to $18 \%$ lower airport charges or 1.3 to $8 \%$ more business to be able to compete with an airport that has no night-time flight restrictions. Similar compensation indices are obtained for airports with only a limited number of night-time slots in comparison to airports with night-time flight prohibitions.

\section{Discussion and conclusion}

Although airport competition has recently received increased attention in air transport research, competition for air freight is a topic that has not been thoroughly studied yet. To contribute to the knowledge in this area, this study focuses on the airport choice for scheduled freighter operations in Europe. While cargo can be transported in the belly of passenger aircraft and in freighter aircraft, we only considered operations that are carried out on a scheduled basis with the latter. Excluding freighter operations by integrators due to their different business model, we estimate that scheduled freighter traffic by combination and all-cargo carriers makes up to 35\% of worldwide air cargo traffic in 2012.

This article first outlines the choice process which airlines deploy when choosing their airports for freighter operations. In this process, airlines consider a myriad of factors on which policy makers and airports sometimes only have limited influence. Governments can, however, stimulate the development of industries that rely on air transport, such as biotech industries, to make a region more attractive for cargo operations. Furthermore, governments can provide a stable regulatory environment for the airlines as well as a framework for night-time flights, which make a region more attractive to airlines. The latter, however, also has to be balanced with the needs of other stakeholders, such as nearby communities. 
The second part of this article concerns a more in-depth analysis of a smaller set of airport choice factors using a stated choice experiment. We performed the experiment to measure the trade-offs that airlines make when choosing between alternative airports. We collected stated choice data from 26 airlines and used this data as input for various logit models. Our results showed that, within the scope of this research, the presence of passenger operations is not a significant factor in the airport choice for scheduled freighter operations. This conclusion does not depend on whether the airline is an all-cargo airline or combination carrier, and to some extent, contradicts previous studies (see Gardiner and Ison (2008)) in which passenger operations turned out to be important for combination carriers. A first reason for this difference between our study and previously published ones can be found in the different scope. While Gardiner and Ison (2008) look at the airport choices worldwide, we only focus on airport choices in Europe, where cargo is often transferred to trucks for the last stretch instead of being transferred to another aircraft. Second, our study only covers freighter operations, which are by nature less related to passenger operations than the transport of air cargo in passenger aircraft. Third, it is not uncommon for experimental studies to yield opposite results than observational studies. The results of observational studies are often over-interpreted and, unjustifiably, causal inferences are drawn from them consciously or unconsciously. From experimental studies, in principle, causal inferences can be drawn. Last but not least, our result may suggest a certain decoupling between all-cargo traffic and cargo traffic transported on passenger flights. This could be an argument for governments to further investigate the possibility of all-cargo airports in order to decrease the pressure on the capacity of major airports. Currently, some regional airports in Europe, such as Liège Airport, succeed in developing their business relying mostly on air cargo. However, governments have to keep in mind that the viability of an all-cargo airport also depends on the total volume of freighter traffic it can attract and whether this will be enough to cover the cost of the airport.

Some authors attribute the increase of competition for freight amongst airports to the shift in market power towards large international forwarders (see, e.g., Andriulaitis (2010)). The consolidation and growth in the forwarding business during the last decades increased the forwarders' market power and therefore their ability to influence a cargo carrier in their airport decision. The results of our stated choice study provide support for this line of reasoning. The estimated models as well as the compensation indices clearly showed the importance of the forwarders' presence in the airport choice, especially for airlines that generally serve main airports. For those airlines, the absence of forwarders at an airport can have a major negative impact on the airport's attractiveness, whereas the presence of a broad range of forwarders has a strongly positive impact on it. Therefore, when aiming to influence airlines in their airport choice decisions, policy makers also have to consider the impact of forwarders.

The importance of the forwarder in the air transport chain might also explain the weak significance of the origin-destination demand in our analyses. The reason why demand turned out to be less important than expected might be due to the fact that there is a certain interdependence between the demand and the 
presence of forwarders. Forwarders are the main customers of the airlines. They often discover (potential) markets first and consolidate freight before bringing it to the airlines. Therefore, airlines, which are interested in the potential market, might view the presence of forwarders as proxy variable for potential demand. When answering the stated choice questions in the survey, the airlines may have based their choices mainly on the presence of forwarders, assuming that, in the presence of sufficient number of forwarders at an airport, there will also be sufficient demand for air cargo.

In our study, the conclusions concerning night-time flight restrictions are twofold: Airlines that mainly serve major airports, on the one hand, do not consider night-time slots to be of importance in the airport choice. Most of these airlines are able to schedule operations around them. Moreover, most main European airports have night-time restrictions or have very high airport charges during the night, so that it is not possible or viable for airlines to operate during the night. On the other hand, we showed that nighttime slots are very important for airlines that mainly serve regional airports. For those, often smaller airlines, night-time flights are essential for optimizing their operations and for the configuration of their route network. For these airlines, the possibility to fly at night is often also an insurance that, if a delay occurs, for example due to extra maintenance, the aircraft will still be able to depart.

Our paper contributes substantially to the as yet limited knowledge about the airport choice for scheduled freighter operations and the competition for air cargo between airports. Our study also sheds a new light on certain driving factors for the airport choice and differences between airlines. Furthermore, our paper contributes to the literature on the airport choice for air cargo and, therefore, adds knowledge to existing studies by Hall (2002), Zhang (2003), Gardiner (see for example Gardiner and Ison (2008) and Gardiner et al. (2005b)) and Watanabe (2009) by applying the stated choice methodology to the airport choice for freighter operations in Europe. Also, it complements and broadens the literature on stated choice by applying this methodology to the air cargo sector.

Based on the choice data collected in the surveys and interviews, not only multinomial logit models were built but also more advanced models like panel mixed logit models. However, to obtain further insights into the taste heterogeneity of airlines in the airport choice, another type of model could be used, the latent class model. While unobserved taste heterogeneity in cross-sectional mixed logit and panel mixed logit models is represented by the random parameters, in latent class models, the taste heterogeneity is described by means of a number of finite classes. In the context of our research, the classes in a latent class model would correspond to different groups of airlines. Also, a model with a latent class structure but assuming preference heterogeneity within each class could be considered (for an example of such a model, see Campbell et al. (2010)).

Furthermore, for airlines who generally serve main airports, the presence of forwarders turned out to be the most important airport choice attribute. Therefore, more research should be carried out further down 
the supply chain, more specifically on how forwarders choose their airports and which attributes influence their decisions.

\section{Acknowledgement}

The authors would like to thank the two anonymous referees for their thorough review of the paper. Their constructive comments and suggestions enabled us to further improve our work. Also, Roselinde Kessels kindly acknowledges the Research Foundation Flanders (FWO) for her postdoctoral research grant.

\section{References}

Air Transport Action Group, 2012. Aviation: Benefits Beyond Border. Geneva.

Andriulaitis, R., 2010. Cargo Capers, in: Canadian Aviation Intelligence Report. Inter VISTAS.

Ashford, N.J., Bencheman, M., 1987. Passenger's Choice of Airport: An Application of the Multinomial Logit Model. Transportation Research Record 1147, 1-5.

Ben-Akiva, M.E., Lerman, S.R., 1985. Discrete Choice Analysis: Theory and Application to Travel Demand. MIT Press, Cambridge, Mass.

Berechman, J., de Wit, J., 1996. An Analysis of the Effects of European Aviation Deregulation on an Airline's Network Structure and Choice of a Primary West European Hub Airport. Journal of Transport Economics \& Policy 30, 251-274.

Bierlaire, M., 2003. BIOGEME: A Free Package for the Estimation of Discrete Choice Models.

Bliemer, M.C.J., Rose, J.M., Hess, S., 2008. Approximation of Bayesian Efficiency in Experimental Choice Designs. Journal of Choice Modelling 1, 98-127.

Campbell, D., Boeri, M., Longo, A., 2010. Accommodating Heterogeneity for Reducing Traffic Pollution: a "Mixed" Latent Class Approach, in: ETC Proceedings 2010. Presented at the European Transport Conference, Glasgow, UK.

Crabbe, M., Vandebroek, M., 2012. Using Appropriate Prior Information to Eliminate Choice Sets with a Dominant Alternative from D-efficient Designs. Journal of Choice Modelling 5, 22-45. doi:10.1016/S1755-5345(13)70046-0

Danielis, R., Marcucci, E., Rotaris, L., 2005. Logistics Managers' Stated Preferences for Freight Service Attributes. Transportation Research Part E: Logistics and Transportation Review 41, 201-215.

Firth, D., 1995. Amendments and Corrections: Bias Reduction of Maximum Likelihood Estimates. Biometrika 82, 667.

Firth, D., 1993. Bias Reduction of Maximum Likelihood Estimates. Biometrika 80, 27-38.

Forsyth, P., Gillen, D., Müller, J., Niemeier, H.-M., 2010. Airport Competition: The European Experience. Ashgate Publishing Limited.

Gardiner, J., Humphreys, I., Ison, S., 2005a. Freighter Operators' Choice of Airport: a Three-stage Process. Transport Reviews 25, 85-102.

Gardiner, J., Humphreys, I., Ison, S., 2005b. Factors Influencing Cargo Airlines' Choice of Airport: An International Survey. Journal of Air Transport Management 11, 393-399.

Gardiner, J., Ison, S., 2008. The Geography of Non-integrated Cargo Airlines: An International Study. Journal of Transport Geography 16, 55-62.

Green, P.E., 1974. On the Design of Choice Experiments Involving Multifactor Alternatives. Journal of Consumer Research 1, 61-68.

Hakfoort, J., Poot, T., Rietveld, P., 2001. The Regional Economic Impact of an Airport: The Case of Amsterdam Schiphol Airport. Regional Studies 35, 595-604. doi:10.1080/00343400120075867

Hall, R.W., 2002. Alternative Access and Locations for Air Cargo. Presented at the METRANS conference, National Technical Information Service, Los Angeles.

Hensher, D.A., Rose, J.M., Greene, W.H., 2005. Applied Choice Analysis: A Primer. Cambridge University Press, Cambridge. 
Hess, S., Polak, J.W., 2010. Airport Choice Behaviour: Findings from Three Separate Studies, in: Forsyth, P., Gillen, D., Müller, J., Niemeier, H.-M. (Eds.), Airport Competition - The European Experience. Ashgate Publishing, pp. 177-196.

Huber, J., Zwerina, K., 1996. The Importance of Utility Balance in Efficient Choice Designs. Journal of Marketing Research (JMR) 33, 307-317.

IATA, 2013. World Air Transport Statistics (WATS) (No. 57). IATA, Montreal.

Ishii, J., Jun, S., Van Dender, K., 2009. Air Travel Choices in Multi-Airport Markets. Journal of Urban Economics 65, 216-227. doi:10.1016/j.jue.2008.12.001

Kessels, R., Jones, B., Goos, P., 2015. An improved two-stage variance balance approach for constructing partial profile designs for discrete choice experiments: An improved two-stage variance balance approach for constructing partial profile designs for discrete choice experiments. Applied Stochastic Models in Business and Industry 31, 626-648. doi:10.1002/asmb.2065

Kessels, R., Jones, B., Goos, P., 2013. An Argument for Preferring Firth Bias-Adjusted Estimates in Aggregate and Individual-Level Discrete Choice Modeling (No. Research Paper 2013-013). Faculty of Applied Economics, University of Antwerp, Antwerp.

Kessels, R., Jones, B., Goos, P., 2011a. Bayesian Optimal Designs for Discrete Choice Experiments with Partial Profiles. Journal of Choice Modelling 4, 52-74.

Kessels, R., Jones, B., Goos, P., Vandebroek, M., 2011b. The Usefulness of Bayesian Optimal Designs for Discrete Choice Experiments. Applied Stochastic Models in Business and Industry 27, 173188.

Kingsley-Jones, M., 2000. Express Delivery. Flight International 158, 43-46.

Kupfer, F., Lagneaux, F., 2009. Economic Importance of Air Transport and Airport Activities in Belgium (No. 158), Working Paper. National Bank of Belgium, Brussels.

Kupfer, F., Van de Voorde, E., Onghena, E., Meersman, H., 2011. World Air Cargo and Merchandise Trade, in: Macário, R., Van de Voorde, E. (Eds.), Critical Issues in Air Transport Economics and Business. Routledge, pp. 98-111.

Martín, J.C., Román, C., Espino, R., 2008. Willingness to Pay for Airline Service Quality. Transport Reviews 28, 199-217.

Page, P., 2003. Selling Cargo. Air Cargo World 93, 44-49.

Rich, J., Holmblad, P.M., Hansen, C.O., 2009. A Weighted Logit Freight Mode-choice Model. Transportation Research Part E: Logistics and Transportation Review 45, 1006-1019. doi:10.1016/j.tre.2009.02.001

Rodrigue, J.-P., 2012. The Geography of Global Supply Chains: Evidence from Third-Party Logistics. Journal of Supply Chain Management 48, 15-23. doi:10.1111/j.1745-493X.2012.03268.x

Rose, J.M., Bliemer, M.C.J., 2009. Constructing Efficient Stated Choice Experimental Designs. Transport Reviews 29, 587-617.

Sándor, Z., Wedel, M., 2005. Heterogeneous Conjoint Choice Designs. Journal of Marketing Research 42, 210-218. doi:10.2307/30164018

Sándor, Z., Wedel, M., 2001. Designing Conjoint Choice Experiments Using Managers' Prior Beliefs. Journal of Marketing Research (JMR) 38, 430-444.

SAS Institute, 2010. JMP. SAS, Cary, NC, USA.

Starkie, D., 2008. Aviation markets - Studies in Competition and Regulatory Reform. Ashgate Publishing, Ltd., Burlington, USA.

Starkie, D., 2002. Airport Regulation and Competition. Journal of Air Transport Management 8, 63-72.

Strale, M., Bonilla, D., 2012. New Logistics Trends and the Airfreight Industry: Evidence from Northwest Europe, in: 16th Air Transport Research Society World Conference. Tainan, Taiwan.

Watanabe, D., Majima, T., Takadama, K., Katuhara, M., 2009. Generalized Weber Model for Hub Location of Air Cargo, in: The Eighth International Symposium on Operations Research and Its Implications. Presented at the ISORA, ORSC \& APORC, Zhangjianjie, pp. 124-131.

Wen, C.-H., Lai, S.-C., 2010. Latent Class Models of International Air Carrier Choice. Transportation Research Part E: Logistics and Transportation Review 46, 211-221. doi:10.1016/j.tre.2009.08.004

Zhang, A., 2003. Analysis of an International Air-cargo Hub: the Case of Hong Kong. Journal of Air Transport Management 9, 123-138. 
Zhang, A., Leung, L.C., Cheung, W., Hui, Y.V., Hui, G.W.L., 2004. Air Cargo in Mainland China and Hong Kong. Ashgate Publishing, Cornwall. 


\section{Appendix A. Bayesian D-optimal partial profile designs for the airport choice experiment}

The stated choice experiment involved four surveys of 20 choice situations. Each survey was taken by six or seven respondents. We created the four surveys by constructing two partial profile designs involving four surveys of 10 choice situations and combining the surveys from the two designs in a pairwise fashion, one survey from each design. We chose this design approach because we suspected that origindestination demand would dominate the airlines' choices. Therefore, one design includes the attribute origin-destination demand, and the other design does not. For each of the four surveys, we randomized all 20 questions.

Tables A.1 and A.2 show the two designs with alternative airports in the different choice situations, including and excluding the demand attribute, respectively. Asterisks indicate attributes not used in the choice situations, which are all described by four attributes. The last line of each table indicates how often each attribute appears in the choice situations of a design. The five-level attributes, 'charges' and 'demand', are used more often than the three-level attributes.

Table A.1 - Six-attribute partial profile design including the 'demand' attribute

\begin{tabular}{|c|c|c|c|c|c|c|c|}
\hline Survey & Choice Set & Night-time & Experience & Forwarders & Passenger & Charges & Demand \\
\hline $\begin{array}{l}1 \\
1\end{array}$ & $\begin{array}{l}1 \\
1\end{array}$ & * & * & $\begin{array}{c}\text { major } \\
\text { broad range }\end{array}$ & $\begin{array}{l}\text { no } \\
\text { sibling }\end{array}$ & $\begin{array}{l}+20 \% \\
-20 \%\end{array}$ & $\begin{array}{l}+20 \% \\
-10 \%\end{array}$ \\
\hline $\begin{array}{l}1 \\
1\end{array}$ & $\begin{array}{l}2 \\
2\end{array}$ & * & $\begin{array}{l}\text { extended } \\
\text { limited }\end{array}$ & * & $\begin{array}{l}\text { different } \\
\text { no }\end{array}$ & $\begin{array}{l}\text { equal } \\
-20 \%\end{array}$ & $\begin{array}{l}\text { equal } \\
-20 \%\end{array}$ \\
\hline $\begin{array}{l}1 \\
1\end{array}$ & $\begin{array}{l}3 \\
3\end{array}$ & * & $\begin{array}{l}\text { limited } \\
\text { extended }\end{array}$ & * & $\begin{array}{l}\text { different } \\
\text { sibling }\end{array}$ & $\begin{array}{l}+10 \% \\
-20 \%\end{array}$ & $\begin{array}{l}+20 \% \\
+10 \%\end{array}$ \\
\hline $\begin{array}{l}1 \\
1\end{array}$ & $\begin{array}{l}4 \\
4\end{array}$ & * & $\begin{array}{c}\text { no } \\
\text { extended }\end{array}$ & $\begin{array}{c}\text { broad range } \\
\text { major }\end{array}$ & * & $\begin{array}{l}-10 \% \\
\text { equal }\end{array}$ & $\begin{array}{l}+10 \% \\
-10 \%\end{array}$ \\
\hline $\begin{array}{l}1 \\
1\end{array}$ & $\begin{array}{l}5 \\
5\end{array}$ & * & $\begin{array}{c}\text { no } \\
\text { limited }\end{array}$ & $\begin{array}{l}\text { broad range } \\
\text { major }\end{array}$ & * & $\begin{array}{l}-20 \% \\
\text { equal }\end{array}$ & $\begin{array}{l}+20 \% \\
+10 \%\end{array}$ \\
\hline $\begin{array}{l}1 \\
1\end{array}$ & $\begin{array}{l}6 \\
6\end{array}$ & $\begin{array}{c}\text { prohibitions } \\
\text { no restrictions }\end{array}$ & * & * & $\begin{array}{c}\text { no } \\
\text { sibling }\end{array}$ & $\begin{array}{l}-10 \% \\
+20 \%\end{array}$ & $\begin{array}{l}-10 \% \\
-20 \%\end{array}$ \\
\hline $\begin{array}{l}1 \\
1\end{array}$ & $\begin{array}{l}7 \\
7\end{array}$ & $\begin{array}{l}\text { no restrictions } \\
\text { limited }\end{array}$ & $\begin{array}{l}\text { limited } \\
\text { no }\end{array}$ & * & * & $\begin{array}{l}+20 \% \\
\text { equal }\end{array}$ & $\begin{array}{l}\text { equal } \\
+10 \%\end{array}$ \\
\hline $\begin{array}{l}1 \\
1\end{array}$ & $\begin{array}{l}8 \\
8\end{array}$ & $\begin{array}{l}\text { no restrictions } \\
\text { limited }\end{array}$ & $\begin{array}{l}\text { limited } \\
\text { no }\end{array}$ & * & * & $\begin{array}{l}+20 \% \\
+10 \%\end{array}$ & $\begin{array}{l}-10 \% \\
\text { equal }\end{array}$ \\
\hline $\begin{array}{l}1 \\
1\end{array}$ & $\begin{array}{l}9 \\
9\end{array}$ & $\begin{array}{l}\text { prohibitions } \\
\text { no restrictions }\end{array}$ & $\begin{array}{c}\text { extended } \\
\text { no }\end{array}$ & * & * & $\begin{array}{l}+10 \% \\
-10 \%\end{array}$ & $\begin{array}{l}+10 \% \\
-10 \%\end{array}$ \\
\hline
\end{tabular}




\begin{tabular}{|c|c|c|c|c|c|c|c|}
\hline $\begin{array}{l}1 \\
1\end{array}$ & $\begin{array}{l}10 \\
10\end{array}$ & $\begin{array}{l}\text { no restrictions } \\
\text { limited }\end{array}$ & $\begin{array}{c}\text { no } \\
\text { limited }\end{array}$ & * & * & $\begin{array}{l}-20 \% \\
\text { equal }\end{array}$ & $\begin{array}{l}\text { equal } \\
-20 \%\end{array}$ \\
\hline $\begin{array}{l}2 \\
2\end{array}$ & $\begin{array}{l}1 \\
1\end{array}$ & * & $\begin{array}{l}\text { limited } \\
\text { extended }\end{array}$ & * & $\begin{array}{l}\text { sibling } \\
\text { different }\end{array}$ & $\begin{array}{l}+20 \% \\
-10 \%\end{array}$ & $\begin{array}{l}+10 \% \\
-20 \%\end{array}$ \\
\hline $\begin{array}{l}2 \\
2\end{array}$ & $\begin{array}{l}2 \\
2\end{array}$ & * & $\begin{array}{l}\text { limited } \\
\text { extended }\end{array}$ & $\begin{array}{l}\text { broad range } \\
\text { major }\end{array}$ & * & $\begin{array}{l}\text { equal } \\
-10 \%\end{array}$ & $\begin{array}{l}\text { equal } \\
+10 \%\end{array}$ \\
\hline $\begin{array}{l}2 \\
2\end{array}$ & $\begin{array}{l}3 \\
3\end{array}$ & * & $\begin{array}{c}\text { no } \\
\text { limited }\end{array}$ & $\begin{array}{c}\text { major } \\
\text { no }\end{array}$ & $\begin{array}{c}\text { different } \\
\text { no }\end{array}$ & $\begin{array}{l}+20 \% \\
+10 \%\end{array}$ & * \\
\hline $\begin{array}{l}2 \\
2\end{array}$ & $\begin{array}{l}4 \\
4\end{array}$ & $\begin{array}{c}\text { limited } \\
\text { no restrictions }\end{array}$ & * & * & $\begin{array}{l}\text { sibling } \\
\text { different }\end{array}$ & $\begin{array}{l}-10 \% \\
\text { equal }\end{array}$ & $\begin{array}{l}\text { equal } \\
-20 \%\end{array}$ \\
\hline $\begin{array}{l}2 \\
2\end{array}$ & $\begin{array}{l}5 \\
5\end{array}$ & $\begin{array}{c}\text { limited } \\
\text { no restrictions }\end{array}$ & * & * & $\begin{array}{c}\text { no } \\
\text { different }\end{array}$ & $\begin{array}{l}-20 \% \\
-10 \%\end{array}$ & $\begin{array}{l}\text { equal } \\
+10 \%\end{array}$ \\
\hline $\begin{array}{l}2 \\
2\end{array}$ & $\begin{array}{l}6 \\
6\end{array}$ & $\begin{array}{c}\text { limited } \\
\text { no restrictions }\end{array}$ & * & $\begin{array}{c}\text { no } \\
\text { broad range }\end{array}$ & * & $\begin{array}{l}-20 \% \\
-10 \%\end{array}$ & $\begin{array}{l}+20 \% \\
\text { equal }\end{array}$ \\
\hline $\begin{array}{l}2 \\
2\end{array}$ & $\begin{array}{l}7 \\
7\end{array}$ & $\begin{array}{c}\text { limited } \\
\text { no restrictions }\end{array}$ & * & $\begin{array}{c}\text { broad range } \\
\text { no }\end{array}$ & * & $\begin{array}{l}+20 \% \\
+10 \%\end{array}$ & $\begin{array}{l}-10 \% \\
+20 \%\end{array}$ \\
\hline $\begin{array}{l}2 \\
2\end{array}$ & $\begin{array}{l}8 \\
8\end{array}$ & $\begin{array}{l}\text { no restrictions } \\
\text { limited }\end{array}$ & * & $\begin{array}{c}\text { major } \\
\text { no }\end{array}$ & * & $\begin{array}{l}-20 \% \\
+20 \%\end{array}$ & $\begin{array}{l}-20 \% \\
+10 \%\end{array}$ \\
\hline $\begin{array}{l}2 \\
2 \\
\end{array}$ & $\begin{array}{l}9 \\
9 \\
\end{array}$ & $\begin{array}{l}\text { no restrictions } \\
\text { limited }\end{array}$ & $\begin{array}{l}\text { limited } \\
\text { extended }\end{array}$ & * & * & $\begin{array}{l}-20 \% \\
-10 \% \\
\end{array}$ & $\begin{array}{l}+10 \% \\
+20 \% \\
\end{array}$ \\
\hline $\begin{array}{l}2 \\
2\end{array}$ & $\begin{array}{l}10 \\
10\end{array}$ & $\begin{array}{l}\text { prohibitions } \\
\text { no restrictions }\end{array}$ & $\begin{array}{l}\text { limited } \\
\text { no }\end{array}$ & $\begin{array}{c}\text { major } \\
\text { no }\end{array}$ & * & $\begin{array}{l}-20 \% \\
\text { equal }\end{array}$ & * \\
\hline $\begin{array}{l}3 \\
3\end{array}$ & $\begin{array}{l}1 \\
1\end{array}$ & * & * & $\begin{array}{l}\text { no } \\
\text { major }\end{array}$ & $\begin{array}{c}\text { no } \\
\text { sibling }\end{array}$ & $\begin{array}{l}\text { equal } \\
+10 \%\end{array}$ & $\begin{array}{l}\text { equal } \\
-20 \%\end{array}$ \\
\hline $\begin{array}{l}3 \\
3\end{array}$ & $\begin{array}{l}2 \\
2\end{array}$ & * & * & $\begin{array}{l}\text { broad range } \\
\text { no }\end{array}$ & $\begin{array}{c}\text { no } \\
\text { different }\end{array}$ & $\begin{array}{l}+20 \% \\
-20 \%\end{array}$ & $\begin{array}{l}-20 \% \\
-10 \%\end{array}$ \\
\hline $\begin{array}{l}3 \\
3 \\
\end{array}$ & $\begin{array}{l}3 \\
3 \\
\end{array}$ & * & $\begin{array}{c}\text { limited } \\
\text { no }\end{array}$ & * & $\begin{array}{c}\text { sibling } \\
\text { no }\end{array}$ & $\begin{array}{l}-10 \% \\
+20 \% \\
\end{array}$ & $\begin{array}{l}-20 \% \\
+20 \% \\
\end{array}$ \\
\hline $\begin{array}{l}3 \\
3\end{array}$ & $\begin{array}{l}4 \\
4\end{array}$ & $\begin{array}{l}\text { no restrictions } \\
\text { prohibitions }\end{array}$ & * & $\begin{array}{l}\text { broad range } \\
\text { major }\end{array}$ & * & $\begin{array}{l}+10 \% \\
-20 \%\end{array}$ & $\begin{array}{l}-10 \% \\
+20 \%\end{array}$ \\
\hline $\begin{array}{l}3 \\
3\end{array}$ & $\begin{array}{l}5 \\
5\end{array}$ & $\begin{array}{c}\text { limited } \\
\text { prohibitions }\end{array}$ & * & $\begin{array}{l}\text { broad range } \\
\text { major }\end{array}$ & $\begin{array}{l}\text { different } \\
\text { sibling }\end{array}$ & * & $\begin{array}{l}+10 \% \\
+20 \%\end{array}$ \\
\hline $\begin{array}{l}3 \\
3\end{array}$ & $\begin{array}{l}6 \\
6\end{array}$ & $\begin{array}{l}\text { limited } \\
\text { prohibitions }\end{array}$ & * & $\begin{array}{c}\text { major } \\
\text { no }\end{array}$ & $\begin{array}{c}\text { no } \\
\text { sibling }\end{array}$ & * & $\begin{array}{l}-20 \% \\
+20 \%\end{array}$ \\
\hline $\begin{array}{l}3 \\
3\end{array}$ & $\begin{array}{l}7 \\
7\end{array}$ & $\begin{array}{l}\text { prohibitions } \\
\text { no restrictions }\end{array}$ & * & $\begin{array}{c}\text { broad range } \\
\text { no }\end{array}$ & $\begin{array}{c}\text { different } \\
\text { no }\end{array}$ & $\begin{array}{l}+10 \% \\
-10 \%\end{array}$ & * \\
\hline $\begin{array}{l}3 \\
3\end{array}$ & $\begin{array}{l}8 \\
8\end{array}$ & $\begin{array}{l}\text { prohibitions } \\
\text { limited }\end{array}$ & * & $\begin{array}{l}\text { broad range } \\
\text { no }\end{array}$ & $\begin{array}{c}\text { no } \\
\text { different }\end{array}$ & $\begin{array}{l}\text { equal } \\
+20 \%\end{array}$ & * \\
\hline $\begin{array}{l}3 \\
3 \\
\end{array}$ & $\begin{array}{l}9 \\
9 \\
\end{array}$ & $\begin{array}{l}\text { prohibitions } \\
\text { limited }\end{array}$ & $\begin{array}{c}\text { extended } \\
\text { limited }\end{array}$ & * & $\begin{array}{c}\text { no } \\
\text { sibling }\end{array}$ & $\begin{array}{l}+20 \% \\
\text { equal }\end{array}$ & * \\
\hline $\begin{array}{l}3 \\
3\end{array}$ & $\begin{array}{l}10 \\
10\end{array}$ & $\begin{array}{l}\text { no restrictions } \\
\text { prohibitions }\end{array}$ & $\begin{array}{l}\text { extended } \\
\text { limited }\end{array}$ & * & $\begin{array}{c}\text { no } \\
\text { different }\end{array}$ & $\begin{array}{l}\text { equal } \\
-10 \%\end{array}$ & * \\
\hline
\end{tabular}




\begin{tabular}{|c|c|c|c|c|c|c|c|}
\hline $\begin{array}{l}4 \\
4\end{array}$ & $\begin{array}{l}1 \\
1\end{array}$ & * & * & $\begin{array}{c}\text { major } \\
\text { no }\end{array}$ & $\begin{array}{l}\text { sibling } \\
\text { different }\end{array}$ & $\begin{array}{l}+10 \% \\
-20 \%\end{array}$ & $\begin{array}{l}-10 \% \\
-20 \%\end{array}$ \\
\hline $\begin{array}{l}4 \\
4\end{array}$ & $\begin{array}{l}2 \\
2\end{array}$ & * & $\begin{array}{c}\text { extended } \\
\text { no }\end{array}$ & $\begin{array}{l}\text { broad range } \\
\text { major }\end{array}$ & * & $\begin{array}{l}+20 \% \\
+10 \%\end{array}$ & $\begin{array}{l}-10 \% \\
+10 \%\end{array}$ \\
\hline $\begin{array}{l}4 \\
4\end{array}$ & $\begin{array}{l}3 \\
3\end{array}$ & * & $\begin{array}{c}\text { no } \\
\text { extended }\end{array}$ & $\begin{array}{c}\text { broad range } \\
\text { no }\end{array}$ & * & $\begin{array}{l}\text { equal } \\
+10 \%\end{array}$ & $\begin{array}{l}+20 \% \\
\text { equal }\end{array}$ \\
\hline $\begin{array}{l}4 \\
4\end{array}$ & $\begin{array}{l}4 \\
4\end{array}$ & * & $\begin{array}{l}\text { limited } \\
\text { extended }\end{array}$ & $\begin{array}{c}\text { major } \\
\text { no }\end{array}$ & $\begin{array}{l}\text { different } \\
\text { sibling }\end{array}$ & * & $\begin{array}{l}\text { equal } \\
-10 \%\end{array}$ \\
\hline $\begin{array}{l}4 \\
4\end{array}$ & $\begin{array}{l}5 \\
5\end{array}$ & * & $\begin{array}{l}\text { limited } \\
\text { extended }\end{array}$ & $\begin{array}{c}\text { no } \\
\text { broad range }\end{array}$ & $\begin{array}{c}\text { no } \\
\text { different }\end{array}$ & $\begin{array}{l}-10 \% \\
+10 \%\end{array}$ & * \\
\hline $\begin{array}{l}4 \\
4\end{array}$ & $\begin{array}{l}6 \\
6\end{array}$ & $\begin{array}{l}\text { prohibitions } \\
\text { limited }\end{array}$ & * & * & $\begin{array}{c}\text { sibling } \\
\text { no }\end{array}$ & $\begin{array}{l}\text { equal } \\
+10 \%\end{array}$ & $\begin{array}{l}\text { equal } \\
-10 \%\end{array}$ \\
\hline $\begin{array}{l}4 \\
4\end{array}$ & $\begin{array}{l}7 \\
7\end{array}$ & $\begin{array}{l}\text { prohibitions } \\
\text { limited }\end{array}$ & $\begin{array}{l}\text { extended } \\
\text { limited }\end{array}$ & * & $\begin{array}{l}\text { sibling } \\
\text { different }\end{array}$ & * & $\begin{array}{l}-20 \% \\
-10 \%\end{array}$ \\
\hline $\begin{array}{l}4 \\
4\end{array}$ & $\begin{array}{l}8 \\
8\end{array}$ & $\begin{array}{l}\text { prohibitions } \\
\text { limited }\end{array}$ & $\begin{array}{l}\text { extended } \\
\text { no }\end{array}$ & * & $\begin{array}{c}\text { no } \\
\text { sibling }\end{array}$ & * & $\begin{array}{l}+10 \% \\
+20 \%\end{array}$ \\
\hline $\begin{array}{l}4 \\
4\end{array}$ & $\begin{array}{l}9 \\
9\end{array}$ & $\begin{array}{l}\text { limited } \\
\text { prohibitions }\end{array}$ & $\begin{array}{l}\text { extended } \\
\text { no }\end{array}$ & $\begin{array}{l}\text { no } \\
\text { major }\end{array}$ & * & * & $\begin{array}{l}-20 \% \\
-10 \%\end{array}$ \\
\hline $\begin{array}{l}4 \\
4\end{array}$ & $\begin{array}{l}10 \\
10\end{array}$ & $\begin{array}{c}\text { prohibitions } \\
\text { no restrictions }\end{array}$ & $\begin{array}{c}\text { limited } \\
\text { no }\end{array}$ & $\begin{array}{l}\text { broad range } \\
\text { major }\end{array}$ & * & * & $\begin{array}{l}+20 \% \\
\text { equal }\end{array}$ \\
\hline
\end{tabular}

Table A.2 - Five-attribute partial profile design excluding the 'demand' attribute

\begin{tabular}{|c|c|c|c|c|c|c|}
\hline Survey & Choice Set & Night-time & Experience & Forwarders & Passenger & Charges \\
\hline $\begin{array}{l}1 \\
1\end{array}$ & $\begin{array}{l}1 \\
1\end{array}$ & * & $\begin{array}{l}\text { extended } \\
\text { limited }\end{array}$ & $\begin{array}{l}\text { broad range } \\
\text { major }\end{array}$ & $\begin{array}{c}\text { no } \\
\text { different }\end{array}$ & $\begin{array}{l}+10 \% \\
\text { equal }\end{array}$ \\
\hline $\begin{array}{l}1 \\
1\end{array}$ & $\begin{array}{l}2 \\
2\end{array}$ & * & $\begin{array}{l}\text { extended } \\
\text { limited }\end{array}$ & $\begin{array}{l}\text { broad range } \\
\text { major }\end{array}$ & $\begin{array}{c}\text { sibling } \\
\text { no }\end{array}$ & $\begin{array}{l}+20 \% \\
+10 \%\end{array}$ \\
\hline $\begin{array}{l}1 \\
1\end{array}$ & $\begin{array}{l}3 \\
3\end{array}$ & * & $\begin{array}{c}\text { extended } \\
\text { no }\end{array}$ & $\begin{array}{l}\text { broad range } \\
\text { major }\end{array}$ & $\begin{array}{c}\text { sibling } \\
\text { different }\end{array}$ & $\begin{array}{l}+10 \% \\
-20 \%\end{array}$ \\
\hline $\begin{array}{l}1 \\
1\end{array}$ & $\begin{array}{l}4 \\
4\end{array}$ & $\begin{array}{l}\text { prohibitions } \\
\text { limited }\end{array}$ & * & $\begin{array}{l}\text { broad range } \\
\text { no }\end{array}$ & $\begin{array}{l}\text { different } \\
\text { sibling }\end{array}$ & $\begin{array}{l}+10 \% \\
+20 \%\end{array}$ \\
\hline $\begin{array}{l}1 \\
1\end{array}$ & $\begin{array}{l}5 \\
5\end{array}$ & $\begin{array}{c}\text { no restrictions } \\
\text { prohibitions }\end{array}$ & * & $\begin{array}{c}\text { no } \\
\text { broad range }\end{array}$ & $\begin{array}{l}\text { different } \\
\text { sibling }\end{array}$ & $\begin{array}{l}+10 \% \\
-10 \%\end{array}$ \\
\hline $\begin{array}{l}1 \\
1\end{array}$ & $\begin{array}{l}6 \\
6\end{array}$ & $\begin{array}{c}\text { prohibitions } \\
\text { no restrictions }\end{array}$ & * & $\begin{array}{l}\text { broad range } \\
\text { major }\end{array}$ & $\begin{array}{l}\text { different } \\
\text { sibling }\end{array}$ & $\begin{array}{l}-20 \% \\
\text { equal }\end{array}$ \\
\hline $\begin{array}{l}1 \\
1\end{array}$ & $\begin{array}{l}7 \\
7\end{array}$ & $\begin{array}{c}\text { limited } \\
\text { no restrictions }\end{array}$ & $\begin{array}{l}\text { extended } \\
\text { limited }\end{array}$ & * & $\begin{array}{c}\text { different } \\
\text { no }\end{array}$ & $\begin{array}{l}-20 \% \\
+10 \%\end{array}$ \\
\hline $\begin{array}{l}1 \\
1\end{array}$ & $\begin{array}{l}8 \\
8\end{array}$ & $\begin{array}{c}\text { limited } \\
\text { prohibitions }\end{array}$ & $\begin{array}{l}\text { extended } \\
\text { limited }\end{array}$ & * & $\begin{array}{c}\text { no } \\
\text { different }\end{array}$ & $\begin{array}{l}-20 \% \\
-10 \%\end{array}$ \\
\hline
\end{tabular}




\begin{tabular}{|c|c|c|c|c|c|c|}
\hline $\begin{array}{l}1 \\
1\end{array}$ & $\begin{array}{l}9 \\
9\end{array}$ & $\begin{array}{l}\text { no restrictions } \\
\text { limited }\end{array}$ & $\begin{array}{l}\text { extended } \\
\text { no }\end{array}$ & * & $\begin{array}{c}\text { no } \\
\text { sibling }\end{array}$ & $\begin{array}{l}+20 \% \\
-10 \%\end{array}$ \\
\hline $\begin{array}{l}1 \\
1\end{array}$ & $\begin{array}{l}10 \\
10\end{array}$ & $\begin{array}{c}\text { limited } \\
\text { no restrictions }\end{array}$ & $\begin{array}{l}\text { limited } \\
\text { no }\end{array}$ & $\begin{array}{c}\text { major } \\
\text { no }\end{array}$ & * & $\begin{array}{l}+10 \% \\
-20 \%\end{array}$ \\
\hline $\begin{array}{l}2 \\
2\end{array}$ & $\begin{array}{l}1 \\
1\end{array}$ & * & $\begin{array}{l}\text { limited } \\
\text { extended }\end{array}$ & $\begin{array}{l}\text { broad range } \\
\text { major }\end{array}$ & $\begin{array}{c}\text { no } \\
\text { sibling }\end{array}$ & $\begin{array}{l}-10 \% \\
+20 \%\end{array}$ \\
\hline $\begin{array}{l}2 \\
2\end{array}$ & $\begin{array}{l}2 \\
2\end{array}$ & * & $\begin{array}{l}\text { extended } \\
\text { limited }\end{array}$ & $\begin{array}{l}\text { broad range } \\
\text { major }\end{array}$ & $\begin{array}{c}\text { no } \\
\text { different }\end{array}$ & $\begin{array}{l}\text { equal } \\
-10 \%\end{array}$ \\
\hline $\begin{array}{l}2 \\
2\end{array}$ & $\begin{array}{l}3 \\
3\end{array}$ & $\begin{array}{l}\text { no restrictions } \\
\text { limited }\end{array}$ & * & $\begin{array}{l}\text { no } \\
\text { major }\end{array}$ & $\begin{array}{c}\text { sibling } \\
\text { no }\end{array}$ & $\begin{array}{l}+20 \% \\
\text { equal }\end{array}$ \\
\hline $\begin{array}{l}2 \\
2\end{array}$ & $\begin{array}{l}4 \\
4\end{array}$ & $\begin{array}{l}\text { limited } \\
\text { prohibitions }\end{array}$ & * & $\begin{array}{l}\text { no } \\
\text { major }\end{array}$ & $\begin{array}{c}\text { different } \\
\text { no }\end{array}$ & $\begin{array}{l}-20 \% \\
\text { equal }\end{array}$ \\
\hline $\begin{array}{l}2 \\
2\end{array}$ & $\begin{array}{l}5 \\
5\end{array}$ & $\begin{array}{l}\text { limited } \\
\text { prohibitions }\end{array}$ & $\begin{array}{c}\text { no } \\
\text { extended }\end{array}$ & * & $\begin{array}{c}\text { no } \\
\text { different }\end{array}$ & $\begin{array}{l}\text { equal } \\
-10 \%\end{array}$ \\
\hline $\begin{array}{l}2 \\
2\end{array}$ & $\begin{array}{l}6 \\
6\end{array}$ & $\begin{array}{c}\text { no restrictions } \\
\text { prohibitions }\end{array}$ & $\begin{array}{c}\text { no } \\
\text { limited }\end{array}$ & * & $\begin{array}{c}\text { sibling } \\
\text { no }\end{array}$ & $\begin{array}{l}-10 \% \\
+20 \%\end{array}$ \\
\hline $\begin{array}{l}2 \\
2\end{array}$ & $\begin{array}{l}7 \\
7\end{array}$ & $\begin{array}{l}\text { no restrictions } \\
\text { limited }\end{array}$ & $\begin{array}{l}\text { limited } \\
\text { extended }\end{array}$ & * & $\begin{array}{l}\text { sibling } \\
\text { different }\end{array}$ & $\begin{array}{l}-10 \% \\
\text { equal }\end{array}$ \\
\hline $\begin{array}{l}2 \\
2\end{array}$ & $\begin{array}{l}8 \\
8\end{array}$ & $\begin{array}{l}\text { no restrictions } \\
\text { limited }\end{array}$ & $\begin{array}{c}\text { no } \\
\text { extended }\end{array}$ & $\begin{array}{l}\text { broad range } \\
\text { major }\end{array}$ & * & $\begin{array}{l}-20 \% \\
+20 \%\end{array}$ \\
\hline $\begin{array}{l}2 \\
2\end{array}$ & $\begin{array}{l}9 \\
9\end{array}$ & $\begin{array}{l}\text { no restrictions } \\
\text { limited }\end{array}$ & $\begin{array}{c}\text { no } \\
\text { limited }\end{array}$ & $\begin{array}{c}\text { major } \\
\text { broad range }\end{array}$ & * & $\begin{array}{l}-20 \% \\
-10 \%\end{array}$ \\
\hline $\begin{array}{l}2 \\
2\end{array}$ & $\begin{array}{l}10 \\
10\end{array}$ & $\begin{array}{l}\text { prohibitions } \\
\text { no restrictions }\end{array}$ & $\begin{array}{c}\text { no } \\
\text { limited }\end{array}$ & $\begin{array}{l}\text { broad range } \\
\text { no }\end{array}$ & * & $\begin{array}{l}\text { equal } \\
+20 \%\end{array}$ \\
\hline $\begin{array}{l}3 \\
3\end{array}$ & $\begin{array}{l}1 \\
1\end{array}$ & * & $\begin{array}{c}\text { no } \\
\text { limited }\end{array}$ & $\begin{array}{c}\text { major } \\
\text { no }\end{array}$ & $\begin{array}{l}\text { different } \\
\text { sibling }\end{array}$ & $\begin{array}{l}+10 \% \\
-20 \%\end{array}$ \\
\hline $\begin{array}{l}3 \\
3\end{array}$ & $\begin{array}{l}2 \\
2\end{array}$ & * & $\begin{array}{l}\text { limited } \\
\text { extended }\end{array}$ & $\begin{array}{l}\text { no } \\
\text { major }\end{array}$ & $\begin{array}{c}\text { no } \\
\text { sibling }\end{array}$ & $\begin{array}{l}\text { equal } \\
+10 \%\end{array}$ \\
\hline $\begin{array}{l}3 \\
3\end{array}$ & $\begin{array}{l}3 \\
3\end{array}$ & $\begin{array}{l}\text { prohibitions } \\
\text { limited }\end{array}$ & * & $\begin{array}{l}\text { broad range } \\
\text { no }\end{array}$ & $\begin{array}{c}\text { different } \\
\text { no }\end{array}$ & $\begin{array}{l}\text { equal } \\
+10 \%\end{array}$ \\
\hline $\begin{array}{l}3 \\
3\end{array}$ & $\begin{array}{l}4 \\
4\end{array}$ & $\begin{array}{l}\text { prohibitions } \\
\text { limited }\end{array}$ & * & $\begin{array}{c}\text { major } \\
\text { no }\end{array}$ & $\begin{array}{c}\text { no } \\
\text { different }\end{array}$ & $\begin{array}{l}-20 \% \\
\text { equal }\end{array}$ \\
\hline $\begin{array}{l}3 \\
3\end{array}$ & $\begin{array}{l}5 \\
5\end{array}$ & $\begin{array}{l}\text { prohibitions } \\
\text { no restrictions }\end{array}$ & * & $\begin{array}{c}\text { major } \\
\text { no }\end{array}$ & $\begin{array}{l}\text { sibling } \\
\text { different }\end{array}$ & $\begin{array}{l}+20 \% \\
+10 \%\end{array}$ \\
\hline $\begin{array}{l}3 \\
3\end{array}$ & $\begin{array}{l}6 \\
6\end{array}$ & $\begin{array}{c}\text { limited } \\
\text { no restrictions }\end{array}$ & * & $\begin{array}{l}\text { broad range } \\
\text { major }\end{array}$ & $\begin{array}{c}\text { different } \\
\text { no }\end{array}$ & $\begin{array}{l}+20 \% \\
-10 \%\end{array}$ \\
\hline $\begin{array}{l}3 \\
3\end{array}$ & $\begin{array}{l}7 \\
7\end{array}$ & $\begin{array}{c}\text { limited } \\
\text { no restrictions }\end{array}$ & $\begin{array}{c}\text { no } \\
\text { limited }\end{array}$ & * & $\begin{array}{c}\text { no } \\
\text { different }\end{array}$ & $\begin{array}{l}-10 \% \\
+10 \%\end{array}$ \\
\hline $\begin{array}{l}3 \\
3\end{array}$ & $\begin{array}{l}8 \\
8\end{array}$ & $\begin{array}{c}\text { no restrictions } \\
\text { prohibitions }\end{array}$ & $\begin{array}{c}\text { no } \\
\text { limited }\end{array}$ & $\begin{array}{l}\text { no } \\
\text { major }\end{array}$ & * & $\begin{array}{l}\text { equal } \\
+20 \%\end{array}$ \\
\hline $\begin{array}{l}3 \\
3\end{array}$ & $\begin{array}{l}9 \\
9\end{array}$ & $\begin{array}{l}\text { prohibitions } \\
\text { no restrictions }\end{array}$ & $\begin{array}{l}\text { extended } \\
\text { no }\end{array}$ & $\begin{array}{c}\text { no } \\
\text { broad range }\end{array}$ & * & $\begin{array}{l}-20 \% \\
+20 \%\end{array}$ \\
\hline
\end{tabular}




\begin{tabular}{|c|c|c|c|c|c|c|}
\hline $\begin{array}{l}3 \\
3\end{array}$ & $\begin{array}{l}10 \\
10\end{array}$ & $\begin{array}{l}\text { prohibitions } \\
\text { limited }\end{array}$ & $\begin{array}{l}\text { extended } \\
\text { no }\end{array}$ & $\begin{array}{c}\text { no } \\
\text { broad range }\end{array}$ & * & $\begin{array}{l}-20 \% \\
+20 \%\end{array}$ \\
\hline $\begin{array}{l}4 \\
4\end{array}$ & $\begin{array}{l}1 \\
1\end{array}$ & * & $\begin{array}{l}\text { limited } \\
\text { extended }\end{array}$ & $\begin{array}{l}\text { broad range } \\
\text { major }\end{array}$ & $\begin{array}{c}\text { sibling } \\
\text { no }\end{array}$ & $\begin{array}{l}+10 \% \\
-10 \%\end{array}$ \\
\hline $\begin{array}{l}4 \\
4\end{array}$ & $\begin{array}{l}2 \\
2\end{array}$ & * & $\begin{array}{c}\text { limited } \\
\text { no }\end{array}$ & $\begin{array}{l}\text { broad range } \\
\text { major }\end{array}$ & $\begin{array}{c}\text { no } \\
\text { sibling }\end{array}$ & $\begin{array}{l}+20 \% \\
+10 \%\end{array}$ \\
\hline $\begin{array}{l}4 \\
4\end{array}$ & $\begin{array}{l}3 \\
3\end{array}$ & * & $\begin{array}{l}\text { limited } \\
\text { extended }\end{array}$ & $\begin{array}{c}\text { major } \\
\text { no }\end{array}$ & $\begin{array}{l}\text { different } \\
\text { sibling }\end{array}$ & $\begin{array}{l}-20 \% \\
-10 \%\end{array}$ \\
\hline $\begin{array}{l}4 \\
4\end{array}$ & $\begin{array}{l}4 \\
4\end{array}$ & $\begin{array}{c}\text { limited } \\
\text { no restrictions }\end{array}$ & * & $\begin{array}{l}\text { no } \\
\text { major }\end{array}$ & $\begin{array}{c}\text { no } \\
\text { sibling }\end{array}$ & $\begin{array}{l}-10 \% \\
\text { equal }\end{array}$ \\
\hline $\begin{array}{l}4 \\
4\end{array}$ & $\begin{array}{l}5 \\
5\end{array}$ & $\begin{array}{l}\text { no restrictions } \\
\text { limited }\end{array}$ & $\begin{array}{l}\text { extended } \\
\text { limited }\end{array}$ & * & $\begin{array}{l}\text { different } \\
\text { sibling }\end{array}$ & $\begin{array}{l}-10 \% \\
-20 \%\end{array}$ \\
\hline $\begin{array}{l}4 \\
4\end{array}$ & $\begin{array}{l}6 \\
6\end{array}$ & $\begin{array}{l}\text { prohibitions } \\
\text { limited }\end{array}$ & $\begin{array}{l}\text { limited } \\
\text { extended }\end{array}$ & * & $\begin{array}{c}\text { sibling } \\
\text { different }\end{array}$ & $\begin{array}{l}-20 \% \\
-10 \%\end{array}$ \\
\hline $\begin{array}{l}4 \\
4\end{array}$ & $\begin{array}{l}7 \\
7\end{array}$ & $\begin{array}{l}\text { no restrictions } \\
\text { limited }\end{array}$ & $\begin{array}{c}\text { no } \\
\text { limited }\end{array}$ & * & $\begin{array}{c}\text { no } \\
\text { sibling }\end{array}$ & $\begin{array}{l}+20 \% \\
\text { equal }\end{array}$ \\
\hline $\begin{array}{l}4 \\
4\end{array}$ & $\begin{array}{l}8 \\
8\end{array}$ & $\begin{array}{l}\text { no restrictions } \\
\text { limited }\end{array}$ & $\begin{array}{l}\text { limited } \\
\text { no }\end{array}$ & $\begin{array}{c}\text { no } \\
\text { broad range }\end{array}$ & * & $\begin{array}{l}\text { equal } \\
+10 \%\end{array}$ \\
\hline $\begin{array}{l}4 \\
4\end{array}$ & $\begin{array}{l}9 \\
9\end{array}$ & $\begin{array}{c}\text { prohibitions } \\
\text { no restrictions }\end{array}$ & $\begin{array}{l}\text { extended } \\
\text { no }\end{array}$ & $\begin{array}{c}\text { no } \\
\text { broad range }\end{array}$ & * & $\begin{array}{l}+10 \% \\
+20 \%\end{array}$ \\
\hline $\begin{array}{l}4 \\
4\end{array}$ & $\begin{array}{l}10 \\
10\end{array}$ & $\begin{array}{l}\text { prohibitions } \\
\text { limited }\end{array}$ & $\begin{array}{c}\text { extended } \\
\text { no }\end{array}$ & $\begin{array}{l}\text { no } \\
\text { major }\end{array}$ & * & $\begin{array}{l}\text { equal } \\
-20 \%\end{array}$ \\
\hline
\end{tabular}




\section{Appendix B. Multivariate normal prior parameter distributions used to construct the Bayesian D-optimal partial profile designs for the airport choice experiment}

This appendix describes the prior parameter distributions used for constructing the two Bayesian Doptimal partial profile designs for the airport choice experiment, shown in Appendix A.

For the six-attribute design including origin-destination demand in Table A.1, the prior distribution is a 16variate normal distribution, and for the five-attribute design excluding origin-destination demand in Table A.2, the prior distribution is a 12-variate normal distribution. To construct the designs and the initial choice model, we assumed all attributes are categorical. Therefore, the total number of parameters equals the sum of the numbers of levels of all attributes minus the number of attributes. As explained in the main text, this enabled us to capture possible nonlinear effects of the attributes on the perceived utility of an airport.

We modeled the attribute levels using effects-type coding. This means that the levels of every 3-level

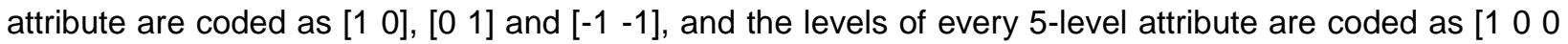

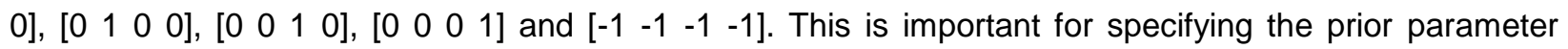
distributions when constructing the choice designs as well as for interpreting the parameter estimates when analyzing the data from the experiment.

To construct the six-attribute Bayesian D-optimal partial profile design including origin-destination demand, we used the 16-variate normal prior distribution $N\left(\boldsymbol{\beta} \mid \boldsymbol{\beta}_{0}, \boldsymbol{\Sigma}_{0}\right)$, with prior mean vector

$\beta_{0}=[-0.7,0.2,-0.7,0.2,-0.6,0.2,0,0,-0.5,-0.25,0,0.25,-0.8,-0.4,0,0.4]^{\prime}$

and prior variance-covariance matrix

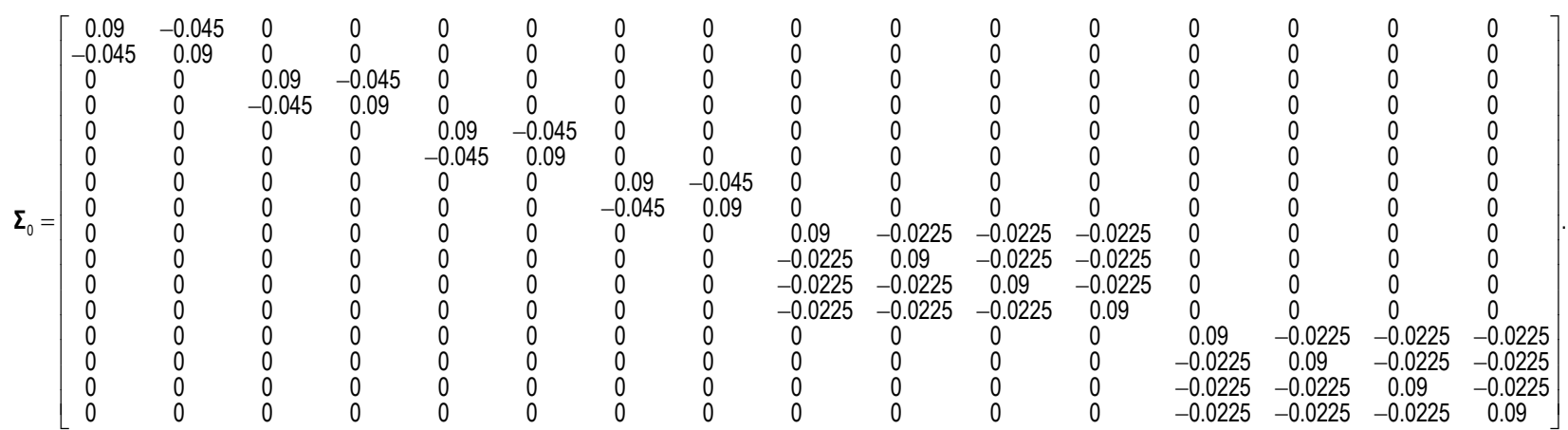

To construct the five-attribute Bayesian D-optimal partial profile design excluding origin-destination demand, we used a 12-variate normal distribution with the same values for the prior mean vector and prior variance-covariance matrix as the 16-variate distribution described above, except for the values for 
the last four dimensions, which concern the demand attribute. Below, we therefore limit ourselves to a discussion of the 16-dimensional prior mean vector and prior variance-covariance matrix.

The 16-dimensional prior mean vector $\boldsymbol{\beta}_{0}$ should be interpreted as follows. The vector's first two elements correspond to the prior utility values of the first two levels of the attribute 'night-time restrictions'. The next two elements correspond to the prior utility values of the first two levels of the attribute 'airport experience with cargo'. The next two sets of two elements correspond to the prior utility values of the first two levels of the attributes 'presence of forwarders' and 'presence of passenger airlines'. Finally, the last two sets of four elements correspond to the prior utility values of the first four levels of the attributes 'airport charges' and 'origin-destination demand'.

The prior mean vector $\boldsymbol{\beta}_{0}$ does not explicitly contain the utility values for the last level of the attributes. Because of the effects-type coding of the attribute levels, the implied utility of an attribute's last level equals minus the sum of all other utility values of that attribute. For example, the implied utility value for no night-time restrictions is 0.5 , indicating that an airport with no night-time restrictions is very attractive for an airline.

The prior distribution also expresses our beliefs that airlines do not favor an airport which has night-time flight prohibitions in place, which has no experience with cargo, which has no forwarders, which has high charges or has low origin-destination demand. This is expressed by the fact that the first element for each of the corresponding attributes in $\boldsymbol{\beta}_{0}$ has the smallest value. The other elements for each attribute have increasing values, indicating that the attractiveness of an airport increases with the level of each attribute.

When designing the experiment, we expected 'origin-destination demand' to be the most important attribute and potentially dominating the airlines' choices. Therefore, we made sure that this attribute was assigned the largest absolute value in the prior mean $\boldsymbol{\beta}_{0}$, namely 0.8 . Similarly, we expected the two attributes 'night-time restrictions' and 'experience with cargo' to be about equally important in a tied second rank, so that we made sure that these attributes were assigned the second largest absolute value in the prior mean $\boldsymbol{\beta}_{0}$, namely 0.7 . The attributes 'presence of forwarders' and 'airport charges' further make up the prior importance ranking with absolute mean values of 0.6 and 0.5 , respectively. For the attribute 'presence of passenger airlines', we had no prior information about the airlines' preferences. This means that prior to the stated choice experiment, we did not know whether an airline prefers an airport without passenger operations or an airport with, for example, different passenger airlines. That is why we specified zero utility values for the first two levels of this attribute. The implied utility value for the last level of the attribute is then also zero. 
For the prior variance-covariance matrix $\boldsymbol{\Sigma}_{0}$, we specified 16 variances that express our uncertainty about the prior utility values contained in the prior mean vector $\boldsymbol{\beta}_{0}$. The variances are all equal to 0.09 , because this preserves the natural rank order of the levels of most attributes. This means that the difference between two consecutive prior utility values for an attribute is usually larger than or equal to the standard deviation of 0.3 . We also specified negative covariances between the utility values corresponding to a single attribute. If $L_{i}$ denotes the number of levels of attribute $i$, we computed these covariances using a correlation coefficient of $-1 /\left(L_{i}-1\right)$. This ensures that the variances of all prior utility values corresponding to a given attribute are the same, meaning that the variance associated with the implied utility of the last level of each attribute also equals 0.09 . 


\section{Appendix C. A note on robust and inaccurate priors}

The design we generated is a Bayesian D-optimal design based on a prior distribution of likely parameter values. Such a design explicitly accounts for the a priori uncertainty about the parameter values. Therefore, it is robust in the sense that it will also be efficient in case the prior means are misspecified to a certain extent. Sándor and Wedel (2001), who originated this type of choice design, demonstrated that Bayesian optimal designs are generally more efficient than locally optimal designs, which are optimized for one prior point parameter vector (Huber and Zwerina, 1996). Because of the fact that Bayesian Doptimal designs account for uncertainty concerning the parameters, the relative attribute ranking specified when planning the experiment may deviate to some extent from the true one without having much effect on the design efficiency. What should be avoided, however, is that the a priori relative importance of the attribute levels is completely wrongly specified. In our stated choice experiment, the natural ordering of the attribute levels matched the estimated ordering, so that the efficiency of the design used for our study is high. 